\title{
Günümüzde Erkeklerin Gözünden Babalık ve Aile
}

\section{Contemporary Fatherhood and the Family from the Male Perspectives}

\section{Özge ZEYBEKOĞLU*}

Özet: Günümüz toplumlarında geleneksel aile yapısının çekirdek aileye dönüşmesi, çekirdek aile yapısı içindeki bireylerin rol ve sorumluluklarının değişmesi, kadının eğitim düzeyinin artması ve ekonomik yönden erkeklere bağımlı olarak yaşamaktan kurtulmaya başlaması kadının toplum içindeki statüsünde değişmelere neden olmuştur. Toplumsal cinsiyet rolleri arasındaki keskin sınırların kalkması anne ve baba rollerinin değişmesini beraberinde getirmiş, babalık kavramı da bu değişimlerden etkilenmiştir. Erkeklerin ev işi ve çocuk bakımıyla ilgili sorumlulukları paylaşmaya başlaması babalık olgusuna ilişkin tutum ve davranışlarda değişime ve babalık olgusuna yeni anlamlar atfedilmesine yol açmıştır. Günümüz toplumlarında geleneksel kültürel inanç ve değerlere sahip annelik-babalıkla modern annelik-babalık uygulamalarının bir arada yaşatıldığı görülmektedir. İlgili literatür incelendiğinde, babalığa ilişkin tutum ve davranışları belirleyen etkenler konusunda gerçekleştirilen çalışmaların yetersiz olduğu ve konuyla ilgili araştırmalara ihtiyaç duyulduğu görülmektedir. Türk toplumunun kültürel yapısı içinde günümüz erkeklerinin babalığa ilişkin tutum ve davranışlarının değişiminde hangi faktörlerin etkili olduğunu saptamak amacıyla gerçekleştirilen bu araştırma literatürde yer alan eksikliği bir nebze de olsa gidermeyi amaçlamaktadır.

Anahtar sözcükler: Aile içi roller, Türk ailesi, cinsiyet rolleri, ana-baba tutumu, Likert Tutum Ölçeği

Abstract: In contemporary societies, the traditional family structure has evolved into a nuclear family structure, thus, the roles and responsibilities of individuals within the nuclear family structure have changed, women's education status has increased and consequently women's status in the society has been raised and women have become independent from being economically dependent upon men. Elimination of the sharp social gender boundaries has changed traditional mother and father roles, in this fashion, the concept of fatherhood is also affected through these developments. Men have started to share housework and child care responsibilities, hence, the nature of fatherhood and parenting attitudes have been changed and the concept of fatherhood and parenting has gained a new meaning. It has being observed that, in today's contemporary societies, traditional and modern cultural beliefs and values for maternity-paternity have existed side by side. After reviewing the relevant literature, it is seen that those studies that have been conducted in order to find the determinants of attitudes and behaviors of fatherhood are inadequate and this topic needs further study and research. This research aims to determine which factors are effective in changing the attitudes and behaviors of men's concept of fatherhood in the cultural structure of Turkish society today, thus, hopefully filling to some extent a gap in this literature.

Keywords: Familial roles, Turkish family, gender roles, parents attitude, Likert Attitude Scale

Sanayileşme, kentleşme ve göç gibi olgular toplumsal yapı ve kurumları derinden etkilemektedir. Değişen toplumsal yapılarda gelenek ve göreneklerin etkisinin azalması, din kurumunun

\footnotetext{
* Yrd. Doç. Dr., Akdeniz Üniversitesi, Edebiyat Fakültesi, Sosyoloji Bölümü, Antalya, ozgezeybekoglu@akdeniz.edu.tr
} 
yönlendirme gücünün zayıflaması, cinsel tabuların belli bir ölçüde yıkılması, kadın-erkek ilişkilerinin geçmişe oranla daha özgürce yaşanması gibi nedenlerle kadının toplum ve aile içindeki rolü ve önemi de değişmektedir. Kadının toplum ve özellikle aile içindeki değișen konumu toplumsal cinsiyet rollerini de etkilemektedir. Tüm bu gelişmelerin doğal bir sonucu olarak evlilik ve aile kurumlarının yapısındaki değiş̧ikliklerin tartışılması gerekliliği ortaya çıkmaktadır. Kadın ve erkeğe ilişkin rollerin ve anlayışların değişimi, aile ve evlilik kurumunun bünyesinde yer alan üç temel grubu etkilemektedir: Çocuklar, kadınlar/anneler ve erkekler/babalar.

Türk aile yapısı bağlamında çocuk ve çocukluğa ilişkin çok sayıda çalışma mevcuttur. Bunların başında özellikle Bekir Onur'un çalışmaları gelmektedir. Bekir Onur, Oyuncak Müzesi (1990) ve Çocuk Kültürü Araştırma ve Uygulama Merkezi'ni (ÇOKAUM, 1994) kurmakla kalmamış aynı zamanda Toplumsal Tarihte Çocuk (1994), Çocuk Kültürü (1997), Cumhuriyet ve Çocuk (1999), Türkiye'de Çocukluğun Tarihi (2005), Çocuk, Tarih ve Toplum (2007), Türk Modernleşmesinde Çocuk (2009) adlı birçok çalışma ortaya koymuştur. Bekir Onur'un yanı sıra, Çiğdem Kağıtçıbaşı'nın yürütücülüğünnde gerçekleşen Çocuğun Değeri Araştırması I (1975) ve Çocuğun Değeri Araştırması II (2003); Mine Tan'ın Çocukluk: Dün ve Bugün - Toplumsal Tarihte Çocuk (1994); ÇOKAUM’un düzenlediği III. Ulusal Çocuk Kültürü Kongresi Bildirilerinin yer aldığı Dünyada ve Türkiye'de Değişen Çocukluk (2001); Mahmut Tezcan'ın Çocuk Sosyolojisi (2005); Hülya Tezcan'ın Osmanlı Sarayının Çocukları (2006); Kemal İnal'ın Modernizm ve Çocuk: Geleneksel, Modern ve Postmodern Çocukluk İmgeleri (2007) ve Çocuğun Örselenen Dünyası (2007); Atalay Yörükoğlu’nun Değişen Toplumda Aile ve Çocuk (2007); Fulya Sormaz'ın Çocukluk, Oyun ve Oyuncak: Sosyo-Kültürel Bir Analiz (2012) olmak üzere önemli çalışmalar bulunmaktadır.

Türk aile yapısı bağlamında çocuk ve çocukluğa ilişkin konularda olduğu gibi, kadını da konu alan çok sayıda çalışma karşımıza çıkmaktadır. Bu çalışmalarda kadının konumu, değeri, emeği, eğitimi, sağlığı, yoksulluğu, siyasal katılımı, anayasal hakları, maruz kaldığı şiddet ve anneliği gibi birçok konu tartışılmış ve tartışılmaya da devam edilmektedir. Kadına ilişkin bütün bu bağlamlarda gerçekleştirilen çalışmaların hepsine burada değinmemiz şüphesiz ki mümkün değildir. Ancak Türk toplumunda aile ve kadına ilişkin çalışmalar çoğunlukla birbirinden ayrılamamakta, aile yapısı tartışılırken kadının ön planda tutulduğu, vurgulandığı çalışmalar yapılmaktadır. Necdet Sevinç'in Eski Türklerde Kadın ve Aile (1987); Aytunç Altındal'ın Türkiye'de Kadın (1991, 2004); Necla Arat'ın Türkiye'de Kadın Olmak (1994); Sibel Özbudun’un Türkiye'de Kadın Olmak (1994); Mahmut Tezcan'ın Türk Ailesi Antropolojisi (2000); M. Cihangir Doğan ve M. Said Doğan'ın Modernleşme Sürecinde Türk Köy Ailesi Araştırması (2005); Latife Kabaklı Çimen'in Türk Töresinde Kadın ve Aile (2008); Leyla Kırkpınar'ın Türkiye'de Toplumsal Değişme ve Kadın (2009); Dilaver Cebeci’nin Tanzimat ve Türk Ailesi (2010); Aile ve Sosyal Araştırmalar Genel Müdürlügüu’nün Türkiye'de Aile Değerleri Araştırması (2010); İsmail Doğan'ın Dünden Bugüne Türk Ailesi (2009); Şirin Tekeli'nin 1980'ler Türkiye'sinde Kadın Bakış Açısından Kadınlar (2010); Ömer Çaha’nın Sivil Kadın - Türkiye'de Kadın ve Sivil Toplum (2010); Şefika Kurnaz’ın Yenileşme Sürecinde Türk Kadını (2011); Saniye Dedeoğlu ve Adem Yavuz Elveren'in Türkiye'de Refah Devleti ve Kadın (2012); Serpil Sancar'in Türk Modernleşmesinin Cinsiyeti - Erkekler Devlet, Kadınlar Aile Kurar (2012); Aile ve Sosyal Politikalar Bakanlığı Kadının Statüsü Genel Müdürlüğü’nün Türkiye’de Kadının Durumu (2012) ve daha sıralayamadığımız birçok çalışma, bu tartışmaların birbirine bağlı bir şekilde gerçekleştiğini gösterir niteliktedir. Benzer bir şekilde toplumsal cinsiyet çalışmaları da, toplumlarda süregelen toplumsal cinsiyete ilişkin kalıpların özellikle kadını olumsuz yönde etkilediği; kadının ikincil konumunu pekiştirdiği ve cinsiyete dayalı ayrımcllığı yeniden ürettiği üzerinde yoğunlaşmaktadır. Söz konusu çalışmalarda kadının kendi aleyhine olan bu süreçleri yeniden 
üretmek ve pekiştirmek konusunda oynadığı aktif rol vurgulanmaktadır. Toplumsal cinsiyet çalışmaları bünyesinde kadına ilişkin pek çok konu farklı açılardan ele alınarak kadın çalışmaları adı altında toplanmaktadır.

Peki ya erkekler... Erkeklerden çoğunlukla ya otorite, güç, iktidar bağlamında ya da tartışılan konunun kadınlarla kıyaslanması sırasında söz edilmektedir. Yalnızca kadını ve kadının yaşadığı sorunları ortaya koymak yeterli midir? Kadın kadar erkeğe ilişkin konuları da tartışmaya açmak gerekmemekte midir? İşte bu noktada, toplumsal cinsiyet çalışmalarının bütünlüğü açısından önem taşıyan erkeklik çalışmaları ortaya çıkmaktadır. Erkeklik çalışmaları erkekliğin yaşanış ve algılanış tarzları arasındaki farklılıkları; egemen erkekliğin yanı sıra farklı erkeklik örüntülerinin varlığını; erkeklik denilen tek bir şeyden söz etmenin imkânsızlığını ve erkekliğe ilişkin daha pek çok konuyu farklı yönleriyle ele almaktadır. 20. yüzyılın sonuna doğru başta feminist kuramcılar olmak üzere önde gelen sosyal bilimciler, eril tahakkümün niteliksel bir değişim yaşamakta olduğunu ve artık ataerkiden değil, yeni türde bir erkek egemenliğinden bahsetmek gerektiğini tartışmaya başlamışlardır. Modernleşmeyle birlikte kadının hem kamusal hem de özel alandaki yeri ve etkinliğinde değişim yaşanmakta ancak kadın-erkek ilişkilerinin dayandığı ataerkil sistem ortadan kalkmamakta, sadece çağa uydurularak "modern" bir biçimde yeniden inşa edilmektedir. Hızlı bir şekilde gelişen sanayileşme ve kentleşmeyle birlikte kadının çalışma hayatına katılımı ve bu katılımın giderek artması, geleneksel geniş aile yapısının çekirdek aileye dönüşmesi ve kadın hareketleri gibi birçok etken erkek(lik) imgesi tartışmasındaki değişimi de beraberinde getirmiştir.

Erkeklik çalışmaları alanında en önemli isimlerden biri olan Connell (2010, 2000, 1995) diğer toplumsal cinsiyetlere tahakküm eden "hegemonik erkek" tipinden bahsetmekte ve onun toplumsal yaşamda bedensel olarak güçlü, yapılı ve kas gücünü kullanmaktan çekinmeyen, duygularını kontrol edip mantığıyla hareket eden bir heteroseksüel erkek olarak temsil edildiğinin altını çizmektedir. Bu imge aslında Türk aile yapısı ve toplumsal hayatı içinde bir babadan beklenilen özelliklerdir denilebilir çünkü Türk toplumunda da bir erkeğin/babanın çelimsiz, güçsüz, duygusal bir insan olması onun zayıflığına işaret etmektedir (bk. Onaylanan kadın ve erkek değerlerine ilişkin sınıflandırma, Navaro, 2007).

Yıldırım’a (2009) göre modernliğin eşitlik ilkesi cinsel kimlikler ve toplumsal cinsiyet rollerine de yansımaktadır. Modernleşen toplumlarda kadın ve erkek çalışma, eğitim, toplumsal ve siyasal katılım konularında eşitlenmektedir. Demokratik toplumların hukuk metinleri bu eşitliğin öncülüğünü yapan üst değerlerdir. Eğitim süreci bunu destekleyen bir kültürel değişim programı uygulamaktadır. Aile kurumu kadınların eşitlik taleplerine göre yeniden rol dağılımına gitmektedir. Kadının aile içindeki rolü, erkekle eşit haklara sahip olma ilkesi doğrultusunda yeniden yapılanmaktadır. Kadın aile içinde erkekle eşitlenerek aynı roller içinde konumlanmaya başlamaktadır. Artık kadın sadece anne değildir, aynı zamanda çalışan, karar veren, meslek sahibi olabilen, bireysel çabalarıyla para kazanabilen bir varlık haline gelmektedir. Evin geçiminde ve kararların alınmasında kadın, erkekle eşit hak ve sorumluluklara kavuşmakta, böylelikle erkek ve kadın işleri biçimindeki rol farklılaşmaları gittikçe ortadan kalkmaktadır (Yıldırım, 2009, 155). İster gelişmiş ister gelişmekte olsun tüm geleneksel toplumlarda kadınlardan beklenen özel alan sınırları içinde ev işleri, çocuk bakımı ve ailenin duygusal/ psikolojik tatmin gereksinimlerini yerine getirmekken, erkeklerden beklenen kamusal alanda başarılı olmak ve ailenin geçimini sağlamaktı. Kadının çalışma hayatına girmesiyle birlikte evin geçimini sağlamak, sadece erkeğin görevi olmaktan çıkmıştır. Geleneksel aile yapısında eviçi/özel alanda tanımlanan kadın, çekirdek aile yapısına geçişle birlikte erkeğe ait olarak tanımlanan kamusal alana çıkmaya başlamıştır. Arslan'ın (2000, 5) da belirttiği gibi kadınların üretim hayatı içinde yer alması insanlık tarihi kadar eski bir olguyken, ücretli çalışması Sanayi 
Devrimi’yle başlamıştır. Kadın işgücü savaşların etkisiyle erkek emeğinin yerine ikame edilmiş ve daha sonraki toplumsal koşullara bağlı olarak nicelik ve nitelik olarak değişim göstermiştir. Savaşların etkisiyle ilk kez çalışma yaşamına ücretli olarak giren kadın eğitim düzeyinin yükselmesi, ekonomik zorluklar nedeniyle kadının gelirine olan gereksinimin artması, ucuz işgücünü oluşturması gibi nedenlerle çalışma yaşamında giderek daha çok yer almaya başlamıştır. Böylece kadınlar anne, eş ve ev kadını üçlemesine bir de çalışan kadın rolünü eklemişlerdir. Kadınların ev kadını ve çalışan kadın rollerini aynı anda yerine getirmelerine bağlı olarak ortaya çıkan sorunlar toplumsal cinsiyet rollerinin de yeniden sorgulanmasını gerekli kılmıştır.

\section{Tarihsel Süreçte Anne(lik) ve Baba(lık)}

Toplumsallaşan, kültür edinen çocuğun yaşam boyu karşılaştığı kişiler içinde en önemlileri şüphesiz, anne ve babasıdır. Annelik ve babalık bir taraftan kültür ürünüdür, diğer taraftan da kültürü oluşturmaktadır. Bu nedenle de annelik ve babalık, insan-kültür ilişkisinin en temel aracısıdır. Çeşitli bilimsel disiplinler annelik ve babalığı farklı açılardan ele almakta ve kavramsal açılkamalar getirmektedir. Örneğin kültürel antropolojide annelik ve babalığa kültürel bir yaklaşım söz konusuyken, gelişim psikolojisinin annelik ve babalığa yaklaşımına kültürel öğe ancak son yıllarda girebilmiştir. Bu gelişmede kültürel ve kültürlerarası psikolojinin yükselişi etkili olmakla birlikte, farklı kültürel ortamlarda gerçekleştirilen araştırmalar annelik ve babalığa özgü değer ve davranışlardaki çeşitliliğe ışık tutmaktadır. Diğer yandan uluslararası göç sonucu çok kültürlü toplumlar haline gelen Batı ülkelerindeki araştırmalar annelik ve babalığa kültürleşme süreci bağlamında eğilmektedirler (Kağıtçıbaşı, 2012, 61).

Aileyi meydana getiren anne, baba ve çocuğa ait roller ve sorumluluklar topluma ve zamana göre farklılıklar içerebilmekte ve tarihsel süreç içinde sosyo-kültürel bağlamda değerlendirilebilmektedir. "Anne ve baba kimdir? Anne ve babanın rolleri ve sorumluluk alanları nelerdir? Bir anne çocuğuna nasıl davranmalıdır? Bir baba çocuğuyla nasıl ilişki kurmalıdır?” gibi soruların cevapları aile, okul, gelenek ve görenekler, bilimsel kaynaklar ve medya gibi küçük ve büyük ölçekli çok çeşitli toplumsallaşma ajanları aracılığıyla bireylere aktarılmaktadır. Biyolojik bir perspektiften bakarsak anne ve babayı anne-baba yapan, doğumuna vesile oldukları birey yani çocuktur. Ancak başlangıcı biyolojik bir nitelik taşıyan çocukluk, annelik ve babalık olguları kendilerini çevreleyen yoğun bir kültürel, tarihsel ve toplumsal bağlamın içinde değerlendirilmekte ve anlamlandırılmaktadır. Hem çocuk hem de anne-baba böyle bir bağlamın içinde toplumsallaşmaktadır (Bağlı, \& Sevim, 2007, 128). Kadınlar ve erkekler, anne-baba olacaklarını öğrendikleri andan itibaren birçok zorlukla karşılaşmaktadır. Bu zorluklardan biri, anne ve baba olmanın sorumluluğunu alamamaktır. Sorumluluğu alamamak, kadının anne rolüne, erkeğin de baba rolüne uyum sağlayamaması anlamına gelmektedir (Öz, 2003, 90).

Annenin, babanın ve çocuğun rolleri, belirli bir toplumun egemen değerlerine ve gereksinimlerine göre belirlenmektedir. İdeolojik fener sadece erkeği/babayı aydınlattığı, ona bütün gücü verdiği zaman anneye gölge düşmekte ve statüsü çocuğunkiyle aynı olmaktadır. Tersi bir durumda, toplum çocukla ve onun eğitimiyle ilgilenirse, fener babanın aleyhine, asıl şahıs olan annenin üzerine çevrilmektedir. Her iki durumda da annenin çocuğa ve babaya karşı davranışı değişmektedir. Toplumun anneliği yüceltmesi veya küçümsemesine bağlı olarak kadın iyi ya da kötü bir anne olacaktır. Bununla birlikte annelik tutumunun tarihinde egemen değerler ve toplumsal buyrukların ötesinde bir başka etken belirmektedir. Bu etken, uzun bir süre birinin diğeri üzerindeki egemenliğiyle kendini gösteren cinsiyetler arasındaki mücadeledir. Kadın ve erkek arasındaki bu çatışmada çocuk önemli bir rol oynamaktadır. Çocuk baba otoritesinin altında kaldığı sürece anne evde ikinci derece roller oynamakla yetinmek zorunda kalmaktadır. Diğer yandan çocuk, anne sevgisinin merkezi olduğu zaman kadın, en azından aile içinde kendisini 
kocasına kabul ettirebilmektedir (Badinter, 1992, 14).

İnsanlar birbirlerini severler, anlaşırlar ve evlenirler. Aynı insanlar gün gelir anlaşamaz ve boşanırlar. İnsanlar karı-koca olmalarını sonlandırabilirken, anne-baba olmalarını sonlandıramazlar. Başka bir ifadeyle, evliliklerin geri dönüşü vardır ancak annelik ve babalığın geri dönüşü yoktur (Öz, 2003, 130). Annelik ve babalık, amaç ve davranışları toplumsal ve kültürel benzerlikler gösteren; aynı bağlamda öğrenilen, sergilenen ve değerlendirilen tutum ve davranışlardır (Baydar, Akçınar, \& İmer, 2012, 83). Türkçe Sözlük’te (2009) “anne” sözcüğü “çocuğunu dünyaya getiren kadın, ana, valide" olarak tanımlanırken, "baba" sözcüğü "çocuğun dünyaya gelmesinde etken olan erkek, çocuğu olmuş erkek, peder” olarak tanımlanmaktadır. Bu tanımlamada da belirtildiği gibi, anne ve baba olmak çocuk sahibi olmayı gerektirmektedir. Annelik ve babalık ebeveynlerin kendi belirledikleri bazı amaçlar doğrultusunda ve çocuklarıyla etkileşim içindeyken sergiledikleri, çocuklarına yönelik davranışların tümü olarak tanımlanabilmektedir (Baydar, Akçınar, \& İmer, 2012, 83).

Aile bağlamında tanımlanan kadın ve erkek konumlarının doğal ve normal olduğu iddia edilmektedir. Doğum biyolojik bir olayken, annelik toplumsal olarak inşa edilmekte, farklı kültürlere göre farklı şekillerde tanımlanmaktadır (Koçak-Turhanoğlu, 2011, 188). İlkel toplumlarda annelik dişi cinsin toplumsal bir işlevidir, bütün kadınlar topluluğun olgusal ya da gizil anneleridir (Reed, 1994, 33). Aile, ilkel toplumlarda anne tarafından oluşturulan, çocuğun dünyaya getirilmesinde rolü bilinmeyen bir babanın varlığına dayanmaktaydı. Kadının çok eşliliğine dayanan bu kurum sınıflı toplumlarda kadının ve erkeğin rollerinin belirli olduğu, erkek egemenliği esasına dayanan tek eşli aileye dönüşürken kadının cinsel özgürlüğü sona ermiştir (Kızılkaya, 2004, 47). Kadınlar doğurganlıklarını kontrol altına aldığından beri bu konuda tüm gelişmiş ülkeleri etkileyen dört olgu ortaya çıkmıştır: Bunlar, doğurganlığın azalması; ortalama annelik yaşının yükselmesi; iş dünyasındaki kadın sayısının artması ve kadınların yaşam tarzlarının çeşitlenmesidir (Badinter, 2011, 25).

Annelik her toplumda yüceltilmektedir. Anne kutsaldır, cennetliktir ve hakkı ödenmez. Bununla birlikte aynı anne eş, yurttaş ya da insan olarak hep erkeklerin gerisindedir. Kadını yücelten de, aşağılayan da erkeklerdir. Annesini el üstünde tutan, kız kardeşine yan baktırmayan erkek, karısını yani çocuklarının annesini ezebilmektedir. Kadınlar da ezildikleri ve aşağılandıkları için kendilerini değersiz hissetmekte, böylelikle kendi cinsine pek değer vermemektedir. Günümüzde de geçerliliğini koruyan önyargılar tarih boyunca sürmüştür: Kadın güçsüzdür, korunmak ister, dedikoducudur, süse düşkündür, sorumsuzdur, parayı idare etmesini bilmez, güvenilir değildir, vefasızdır, zeki değildir... vb. Bununla birlikte girişken, becerikli, zeki kadından çekinilmekte; tutkulu, becerikli ve kendine güvenen kadın yadırganmakta, çünkü o sınırını aşarak erkekle yarışa girmektedir (Yörükoğlu, 2007, 65).

Annelik, kadınları güçlendiren deneyimlerden birisidir çünkü kadınlara, kendilerini var edebilecekleri meşru bir alan sağlamaktadır. Bu varlık alanının son derece sıkı bir biçimde sınırları çizilmiş olsa da, güçlendirici bir etkisi olduğu şüphesizdir (Bora, \& Üstün, 2008, 14). Batılı kadınların çoğunluğu prensip olarak kadınlık meseleleriyle annelik arzuları arasında seçim yapma olanağına sahiptir. Bir yandan bağımsızlıklarını sağlayacak koşulları, bir meslekte kendilerini gösterme olanağını, parlak bir ilişki ve sosyal hayatı, diğer yandan da annelik deneyimini ve bir çocuğun sağladığı bütün mutlulukları ve sevgiyi arzulamaktadırlar. Bu ideale ulaşmak için daha geç yaşta ve daha az sayıda çocuk yapmaktadırlar. Bununla birlikte ilk çocuk doğar doğmaz kendilerini sahip oldukları iki ayrı kimlik arasında bir müzakereci konumunda bulmaktadırlar. Kadınlık ve annelik kimlikleri arasındaki denge hassas ve değişkendir. İki ayrı kimlik arasındaki müzakere hiçbir zaman tam anlamıyla bitmemekte, çocuğun yaşına ve ihtiyaç- 
larına, kadının mesleki durum ya da fırsatlarına göre gelişebilmektedir (Badinter, 2011, 131133).

Babalığın fizyolojik gerçeğinin kavranması babalık duygusuna yepyeni bir unsur ekleyerek hemen her yerde ataerkil toplumların doğmasına yol açmıştır. Babanın, İncil’de belirtildiği gibi, çocuğun kendi "tohumu" olduğunu kavramasıyla birlikte ona karşı olan duygusunu iki etken güçlendirmiştir: iktidar tutkusu ve dölün devamı. Erkek, döllerinin başarısını kendi başarısı olarak duymakta ve onların yaşamını kendi yaşamının devamı olarak görmektedir. Babalığın ortaya çıkması insan toplumunu anaerkil evreden daha rekabetçi, enerjik, dinamik ve çalışkan hale getirmiştir. Bir ölçüde varsayıma dayanan bu etkinin dışında eşin (kadının) namusu üzerinde durmak için artık yeni ve çok önemli bir neden vardır. Babalığın ortaya çıkması, kadınların namuslarının korunması adına baskı altına girmelerine yol açmıştır (Russell, 1999, 19-20).

Batı’da çağlar boyunca hüküm süren "baba egemenliği” 19. yüzyılda önemli bir değişim geçirmiştir. 17. ve 18. yüzyıllarda iş ve ev henüz mekânsal olarak birbirinden çok fazla ayrılmadığı için babalar zamanlarının büyük bir kısmını evde geçiriyor, zanaatlarını çocuklarına öğretiyor, sürekli onların yakınında bulunarak onları eğitmekle kalmıyor, ahlaki değerleri de aşılıyorlardı. 19. yüzyılda kapitalizmin gelişmesiyle birlikte babalar, fabrikalarda çalışmaya başladı. Böylelikle 19. yüzyılda Batı'da çalışma yaşamı ve kamusal alan erkeğin, ev ve aile yaşamıysa kadının alanı olarak inşa edildi. Öte yandan 19. yüzyılın ikinci yarısından itibaren boş zamanın artmasıyla birlikte erkekler, iş dışındaki zamanlarını evlerinde değil, içki salonlarında, kulüplerde ve spor salonlarında geçirmeye başladılar. Önceki yüzyıllarda babanın zamanının büyük bir kısmını evde geçirmesi doğal kabul edilirken, 19. yüzyılda bu durum "erkeksi olmayan" bir davranış olarak değerlendirilir hale geldi. 19. yüzyılın orta sınıf babalığı "erkek kamusallığının ciddiyetine yaraşır bir biçimde”, babanın işi dışındaki sınırlı zamanında çocukları mesafeli ama güçlü bir denetim altında tutuyordu. Bu kontrolün maddi bir zemini de vardı. 19. yüzyılda baba evin geçimini sağlayarak mali olarak tüm aile bireylerini kendine bağımlı hale getiren tek aktördü. Evin reisi olan babalar, eşleri ve çocukları üzerindeki haklarıyla, kadınlarsa ev ve çocuk bakımına ilişkin görevleriyle birlikte anılmaktaydı (Çabuklu, 2007, 101-103).

Çabuklu’ya (2007) göre, 19. yüzyılda babalığın toplumsal olarak kuruluşu, ulus-devletin kurulmasıyla yakından ilişkiliydi. Daha önceki yüzyıllarda desteğini önemli ölçüde yerel güçlerden alan ataerki, 19. yüzyılda ulus-devletle iç içe geçecekti. Bu dönemde erkeklik kendini, gündelik aile hayatının ötesinde bir alan olarak kamusal ve politik alanda, soyut yüksek düşünce, felsefe ve bilim alanında inşa etmeye girişmişti. Erkekliğin ve babalığın "yüksek menfaatleri” bireysel babalığın bir müzakere süreci içinde yeniden düzenlenmesini, bir anlamda devletin kontrolü altına girmesini beraberinde getirecekti. Çocuk giderek artan ölçüde evde babalar tarafından eğitilmek yerine “devlet babanın” tek tipleştirici kurumları (okul, çocuk ıslahevleri, sosyal hizmet uzmanları, vb.) tarafından biçimlendirilecek, disipline edilecekti. Devletin yani kurumsal ataerkinin aileye el atma girişimleri 20. yüzyılın ilk yıllarında hız kazandı. Bu müdahalenin önemli bir nedeni 20. yüzyılın başlarından itibaren kadın hakları hareketlerinin güçlenmesiyle kadınların sosyal yaşama giderek daha fazla katılmalarıydı. Bu durumda devlet, evin kontrolünü sadece bireysel babaların inisiyatifine bırakmayı yetersiz buluyordu. Bireysel babalığa ilişkin yeni bir söylem geliştirerek anne-çocuk ilişkisini denetim altına almaya çalışacaktı. 1920'lerde erkek çocukların anneleriyle yakın ilişkisinin bu çocukları "efemineleştireceği” yolunda endişeler mevcuttu. Uzmanlar bu durumun çocukta anne saplantısına, bağımlılığına yol açabildiğini, çocukların olgunlaşmasını engellediğini söylüyorlardı. Bu durumda babanın erkek çocuklarıyla daha fazla ilgilenmesi, onlara erkeklik değerlerini aşılaması gerekmekteydi. Bununla birlikte zorunlu hale getirilen eğitim, erkek çocukları anne bağımlılığından bir ölçüde kurtararak, okulda eril ideoloji çerçevesinde biçimlendiriyordu. Ancak bu biçimlen- 
dirme yeterli değildi. Aile içinden de bir öznenin yani babanın desteği gerekmekteydi (Çabuklu, 2007, 103-105).

Sosyo-ekonomik, politik, kültürel ve bilimsel alandaki değişmeler de erkeklerin nasıl bir baba olacağını önemli ölçüde etkilemektedir. Dünyadaki hızlı değişmelerden babalık kavramı da etkilenmektedir (Güngörmüş-Özkardeş, 2010, 19). Batı’da 1970’ler sonrasında piyasaya sürülecek olan “yeni baba” idealinin ilk tohumları 1920'lerden itibaren atılmaya başlamıştır. LaRossa’ya (1996) göre bu orta sınıf baba, işten eve geldikten sonra -özellikle erkek- çocuklarıyla oyun oynuyor, onlara yakınlık gösteriyor, hafta sonlanı onlarla birlikte geziyor, onlara futbol oynamayı öğretiyordu. Böylece "paradoksal bir biçimde” evcillik erkeksileștirilirken aynı zamanda erkeklik evcilleştirilmekteydi. Ancak "babanın evcilleşmesi” yüzeyseldi, vitrinin ötesine geçmiyordu. Babalar çocuklarıyla oyun oynayıp onlara daha arkadaşça davranıyorlardı ama bu iş bu kadarla sınırlı kalıyordu. Bebeklerin altını değiştirmek, onları yedirmek, uyutmak, yıkamak gibi işler yine anneye aitti (Akt. Çabuklu, 2007, 105). İkinci Dünya Savaşı sırasında babaların askerde olması, evde erkek rolü modelinden mahrum kalan çocukların "efemineleşebileceği” korkusunu yeniden gündeme getirecekti. Babasız yetişen çocukların "daha az erkeksi” olacakları düşünülmekteydi. ABD'de İkinci Dünya Savaşı’ndan sonraki dönemde banliyölerde babanın sorumlulukları söylemi güç kazandı. 1950'lerde babalık bir "hobi” olarak sunulmaya başlandı ve güler yüzlü, sıcak baba imajı güçlendirildi. Batı'da 1970’li yıllardan sonra babalığa ilişkin yeni bir söylem kurulmaya başlandı. Ev işleriyle, çocuklarıyla daha fazla ilgilenen, bu konularda karısıyla işbirliği yapan “yeni baba” imajı gelişti. İkinci dalga feminizmin mücadelesiyle babanın çocuğun fiziksel bakımına daha fazla katılması yönünde bir baskı oluştu. Öte yandan 1970’lerde gelişmeye başlayan post-fordist hizmet ekonomisi, kadınların iş hayatına yoğun bir biçimde katılmasını beraberinde getirirken, babanın evin geçimini tek başına sağlama özelliğini zayıflatmaya başladı. Çalışan kadınlar kocalarından ev işlerine ve çocukların bakımına daha fazla katılmalarını talep eder hale geldi (Çabuklu, 2007, 105-106).

Çocuklar kadınların hayatına olduğu gibi, erkeklerin hayatına da sevinç ve anlam katmaktadırlar. Babalık rollerini yerine getirmelerine izin verilmediğinde erkekler giderek daha öfkeli ve şiddet yanlısı olabilmekte, yaşama isteklerini kaybedebilmektedirler. Sosyolog Kposowa, 1979 yılından itibaren dokuz yıllık bir süre içinde yaklaşık 472.000 erkek ve kadının ölüm nedenlerini incelediği araştırmasında, boşanmış veya eşinden ayrı yaşayan bir erkeğin kendini öldürme ihtimalinin evliliği devam eden bir erkeğe oranla iki kat fazla olduğunu gözlemlemiştir (Akt. Diamond, 2006, 182). Eggebeen ve Knoester'ın (2001) babalık hakkında yaptıkları çalışmalarının sonuçlarına göre, baba olan erkekler baba olmayan erkeklere kıyasla psikolojik ve sağlık durumları açısından farklılaşmamakta ancak bu iki grup arasında toplumsal ve aile ilişkileri ve iş yaşamları açısından önemli farklar bulunmaktadır. Bununla birlikte, Osherson (1986) da çocukları yuvadan ayrılan babaların önemli bir kısmının "boş yuva sendromu” adı verilen olumsuz duygularla dolu bir süreç yaşadığını gözlemlemiştir.

Osherson’un (1986) babalıkla ilgili araştırmasından edindiği bulgular üç önemli başlıkta özetlenebilir:

1. Erişkin erkekler büyürlerken babalarından yeterli derecede "babalı" görmediklerini belirtmişlerdir.

2. Babalarını ve “babalı̆̆ı” görmediğini belirten bu erkeklerin “babalık” hakkındaki görüşleri gerçeği yansıtmayacak derecede karmaşık ve zedelenmiştir.

3. Babalık ve babalarıyla ilgili karmaşık düşünceleri erkeklerin bir rol olarak kendi babalıklarını ifa etmelerini de zorlaştırmaktadır.

Babalık tanımı topluma, kültüre ve döneme göre değişebilmekle birlikte değişmeyen iki ortak 
özelliğe sahiptir. Babalıkla ilgili çalışmalar 1980’li yıllardan önce başlamakla birlikte, 1990’lı yıllarda uluslararası düzeyde daha yaygın bir biçimde tartışlır olmuştur. Babalara yönelik bu ilginin artması ve babalık rolünün değişmesinde en önemli etken kadın olmuştur. Kadının toplum içindeki konumunun değişime uğraması babanın rolünün değişmesini de beraberinde getirmiştir. Kadının toplum içinde değişen konumuna yönelik ilk akla gelenler şunlardır (Güngörmüş-Özkardeş, 2010, 19-20):

- Ekonomik alandaki değişmelerin kadın-erkek rollerini etkilemesi,

- Çalışan kadın sayısının artması,

- Kadının tam gün dışarıda çalışmasına bağlı olarak erkeklerin evle ilgili sorumlulukları paylaşmaları zorunluluğunun oluşmasına bağlı olarak çocuk bakımıyla ilgili yeni düzenlemelerin gerekli olması,

- Evin idaresinin çoğunlukla kadında olması,

- Kadının yüksek eğitim görmesi ve iş bulabilir olması,

- Ekonomik açıdan erkeklerden daha bağımsız hale gelmesi,

- Özellikle Batılı toplumlarda daha çok sayıda boşanmış ya da dul erkeğin tek başlarına çocuklarının bakım ve eğitim sorumluluğunu üstlenmeleri gerekliliği,

- Geleneksel aile yapısının çekirdek aileye dönüşmesi, aile destek sistemlerinin zayıflaması ve çekirdek aile içindeki bireye dönüşen rol ve sorumlulukların değişmesi,

- Küreselleşen dünyada göç olgusunun artması.

Türkiye'de annelik ve babalık davranışlarını kapsamlı bir şekilde inceleyen Ailede Çocuk Eğitimi Araştırması (1995), (Daha ayrıntılı bilgi için bakınız: Ailede Çocuk Eğitimi Araştırması, 1995, http://www.ailetoplum.gov.tr/upload/athgm.gov.tr/mce/eskisite/files/Kutuphane_18_Aile _Cocuk_Egitimi_Arastirmasi.pdf, erişim tarihi:13.01.2013), Türkiye'de ailelerin çocuklarını nasıl yetiştirdikleri, eğittikleri, tanımladıkları; onlara hangi değerleri ve rolleri atfettikleri, nasıl bir fiziki ve psikolojik çevre hazırladıkları; onlardan neler bekledikleri ve çocuk eğitimi açısından hangi konularda benzeşip hangi konularda farklılaştıklarına ilişkin kapsamlı veriler elde etmek amacıyla gerçekleştirilmiştir. Araştırma bulgularına göre, Türkiye'de çocuk eğitimi konusunda annelerin bazı farklılıklara rağmen, birçok açıdan benzer değerleri ve tutumları benimsedikleri görülmüştür. Annelerin büyük bir çoğunluğu yakın ilgi ve sevgi eşliğinde, çocuklarını kendi ayakları üzerinde durmaya teşvik eden, ılımlı bir denetim ile yetiştirmektedirler. Bununla birlikte, annelerin büyük bir çoğunluğunun çocuklarını cinsiyet ayrımı yapmadan yetiştirdikleri de gözlenmiştir. Bu doğrultuda annelerin kendilerine ve onları izleyen kuşaklardaki kız çocuklarına yaptıkları cinsiyet atıfları da, kadınların çağdaş ve demokratik değerlere önemli ölçüde yatkın olduğunu ortaya koymuştur. Anneler arasında çocuğa verilen maddi değer giderek azalırken psikolojik değerin artması ve büyüklere olan tam itaatin düşüşe geçen bir değer halini alması çocuğa psikolojik gelişimi için mümkün olduğunca uygun bir fiziksel ve psikolojik çevrenin sağlanmaya çalışıldığını da göstermiştir. Annelerin bu eğilimleri, sosyo-ekonomik gelişmişlik göstergelerine göre anlamlı derecede farklılıklaşmaktadır. Sosyo-ekonomik açıdan gelişmiş kentsel kesimde yaşayan, eğitim düzeyi görece yüksek, çalışma eğilimi fazla, çocuk sayısı az olan ve görece yüksek gelirli ailelere mensup kadınların "yetkin" çocuk yetiştirme özelliklerini, çocuğa psikolojik değer ve çağdaş cinsiyet rolü atıflarını, daha zengin bir fiziki ve psikolojik çevre sağlama eğilimlerini çok daha güçlü biçimde taşıdıkları sonucuna ulaşılmıştır. Kentten kırsala doğru gidildikçe, annenin eğitim düzeyi ve çalışma eğilimi düştükçe, çocuk sayısı arttıkça ve hane geliri azaldıkça çocuk yetiştirme de geleneksel, katı, yetkeci ya da çocuğu ihmal eder boyutta serbest tutumlar ağırlık kazanmakta; büyüklere tam itaat beklentisi ön plana geçmekte; cinsiyet rollerinde geleneksel atıflar, çocuğa maddi değer yükleme ve daha 
kısıtlı bir fiziki ve psikolojik çevre hazırlama eğilimleri güçlenmektedir. Annelerin erkek çocuk istekleri ve tercihlerinin hangi kesimde olursa olsun önemli ölçüde gerilediği görülmekle birlikte kız çocuklarının eğitimi konusunda da erkeklerle eşit düzeyde okutulmasından yana oldukları görülmüştür. Ancak bazı geleneksel değerlerin gücünü hala koruduğu da unutulmamalıdır. Çocuğun yetiştiği, eğitildiği ilk ve temel ortam olan ailenin kadın/anne tarafından temsil edilen kısmı, çağdaşlaşma yönünde ciddi bir değişim içindedir. Bu değişim ister çocuk üzerinde uygulanan kontrolün niteliği, derecesi, çocuğa verilen değer ve çocuktan beklentiler, isterse çocuğa atfedilen roller ve çocuğa sağlanan fiziksel ve psikolojik çevre söz konusu olsun belirgin bir biçimde ortaya çıkmaktadır. Kadınlar/anneler geleneksel rollerden, değerlerden uzaklaşan ya da en azından uzaklaşmak isteyen-, çağdaş rol ve değerlere yaklaşan tutum ve eğilimler ortaya koymuşlardır. Ailede Çocuk Eğitimi Araştırması (1995) ailede çocuk eğitimini daha çağdaş ve demokratik düzeye getirmek için sosyo-ekonomik gelişmenin hızlandırılması; kentleşmenin hızlanması; kadının örgütlü çalışma yaşamına daha etkin bir biçimde katılması; kadının eğitim düzeyinin yükseltilmesi ve kadının doğurganlık hızının yavaşlatılması gerektiğini belirtmiştir.

\section{Günümüzde Babalık İmgesi}

Günümüz aile yapıları içindeki baba-çocuk ilişkisi incelendiğinde baba figürünün çocuğun zekâ, kişilik ve cinsel gelişimi başta olmak üzere birçok konuda etkili olduğu görülmüştür. Buna ek olarak, babasız çocukların okul başarılarının diğer çocuklara oranla daha düşük olduğunu gösteren çok sayıda çalışma mevcuttur. Aslında tek başına bu çalışmalar bile babanın önemini anlamak için yeterlidir. Bu nedenle artık anneliğin yanı sıra babalık ve baba figürü üzerine yapılan çalışmalar da hız kazanmıştır. Toplumsal cinsiyet rolleri arasındaki keskin sınırların kalkması ve kadının toplum içindeki konumunun yükselmesi anne ve baba rollerinin değişmesini sağlamış, babalık kavramı da bu değişmelerden etkilenmiştir.

Erkekler eril tahakkümü nasıl öğrenir? Eril tahakküm ne ölçüde babadan öğrenilen bir alışkanlıklar bütünüdür? Erkek üstünlüğüne dayalı bir toplumsal çevreye doğan bir erkek, cinsiyet eşitliğini benimseyebilir mi? Bir erkeğin nasıl bir babanın çocuğu olduğu onun eşitlikçi tutumlar benimsemesini ne ölçüde belirler ya da engeller? Cinsler arası ayrım ve eşitsizlik ne ölçüde aileden/babadan öğrenilir? Bütün bu soruların cevapları çoğu insan için oldukça basittir çünkü genel kabul gören görüş, babaların sahip olduğu erkeklik değerlerinin "rol modeli” olarak çocuklarına da büyük ölçüde geçtiği yönündedir. Babadan oğula geçen erkekliğin büyük ölçüde doğal/biyolojik, bu nedenle de değişmez bir özellik olduğu da bu kabullerin temelinde yatan düşüncedir. Özcülük olarak nitelenen bu görüşün temel varsayımı, annelik ve babalık davranışlarının biyolojik/genetik kökenli olduğu yönündedir. Bununla birlikte, babaların erkek olarak ebeveynlik yapma tarzı özellikle erkek çocuklar için oldukça önemlidir. Çocukları heteroseksüel evliliğe hazırlayan, özellikle babaların "doğruerkek” rolüne uygun davranışlarıdır. Bununla birlikte babadan oğula geçecek biyolojik/genetik kökenli bir erkeklik olduğunu varsaymak çok sorunludur. Çünkü erkekliğin babadan öğrenildiği tezi somut verilerle kolayca doğrulanamamaktadır (Marsiglio, \& Pleck, 2005’ten akt. Sancar, 2009, 125).

Yeni doğan bir bebeğin bütün dünyası anneden ibaretken, baba bebeğin gözünde anne dışındaki ilk yetişkin olarak algılanmaktadır. Babanın çocuğun dünyasındaki işlevi döllenmiş yumurtayla birlikte başlamaktadır. O andan itibaren babanın, doğacak olan bebeğin sorumluluğunu paylaşması, hamilelik sürecinde anneyi desteklemesi annenin duygusal yükünü hafifletmektedir. Babanın bu desteğinin doğumu olumlu etkilediğini ve doğum sonrası dönemde sıcak anneçocuk ilişkisinin nedeni olduğunu kanıtlayan araştırmalar mevcuttur. Doğumun ardından etkili bir güven sigortası ve özdeşim modeli olarak babanın, çocuğun gelişim sürecinde özel bir önemi bulunmaktadır. Türkiye’de yeterince irdelenmeyen baba-çocuk ilişkisini Güngörmüş Özkardeş 
(2010) değişen dünya koşullarında değişim gösteren baba figürü bağlamında ele almaktadır. Çocuklar söz konusu olduğunda daha çok anne-çocuk arasındaki ilişki ve etkileşim üzerinde durulmakta ve bu ilişkinin hem anne hem de çocuk için ne kadar önemli olduğu vurgulanmaktadır. Bu etkileşim içinde baba unutulmakta hatta yok sayılmaktadır. Uzun bir süre babanın çocuk üzerindeki olası etkileri önemsenmemiş, hatta antropolog M. Mead daha da ileri giderek babaların sadece biyolojik açıdan gerekli olduğunu, sosyal açıdansa bir kaza olduklarını ifade etmiştir (Güngörmüş-Özkardeş, 2010, 11-16).

Baba olmak, erkek olmanın anlaşılması en zor hallerinden birisidir. Bir erkek için baba olmak, kadınların "doğurarak anne olmak" bağlantısı kadar somut bir durum değildir. Anne olmaktan farklı bir şekilde baba olmak, çocuk ile babası olan erkek arasında doğrudan biyoloji yoluyla açık ve belirgin bir ilişki olarak kurulamamakta, bir kadının/annenin onayına ve kabulüne muhtaç niteliğine bağlı olarak babalık belirsizlik riski taşımaktadır. Hukuki ve kültürel boyutlarının yanı sıra, bir erkeğin baba olmasının bir anlamı vardır: Baba olmak, çocuğunun ve -çoğu zaman- çocuğunun annesinin geçimini sağlamaktır. Babalık geçim sağlamakla bağlantılı olduğu ölçüde, her şeyden önce işgücü piyasasında bir konum demektir. Bu konum babalığı istihdam biçimleriyle ilişkili hale getirmektedir. Tam gün bir işte çalışan ve gelirini arttırabilmek için çoğu zaman daha uzun çalışma saatlerine katlanmak zorunda kalan bir erkeğin babalık yapma biçimiyle geçimi sağlama sorumluluğunu paylaşan, daha esnek ve rahat çalışma saatleri olduğu için çocuğuyla daha fazla zaman geçirebilen ve çocuğunun bakımı, eğitimi gibi sorumlulukları anneyle paylaşan bir babanın konumu birbirinden çok farklıdır (Sancar, 2009, 120121). Latin Amerika ülkelerinde babalıkla ilgili yapılan çalışmalar ataerkil bir toplum yapısına sahip olmasına vurgu yapılan bu ülkelerde babalık kavramının karmaşık anlatım ve duygularla dolu olduğunu göstermektedir. Cruzat, \& Aracena (2006) Şili’li genç erkeklerin babalıkla ilgili duygu ve düşüncelerini yarı yapılandırılmış görüşme tekniği aracılığıyla toplayarak incelemiş ve babalığa geçişin sorunlu ve kaygılı bir süreç olduğunu ve böylesi bir sürecin erkeklerin babalıkla ilgili düşüncelerini daha da karmaşıklaştırdığını ortaya koymuştur. Örneğin, katılımcılar genel olarak baba olmayı istemekte ancak ekonomik zorlukların onların iyi birer baba olacaklarına dair umutlarını azalttığını göstermektedir. Olavarría (1999) genç erkeklikten babalığa geçiş döneminin türlü bireysel ve toplumsal sorunlar ve karmaşık duygu ve düşüncelerle dolu olduğunu, bu nedenle de erkeklere yönelik ve özellikle onların babalığa geçişlerini kolaylaştıracak kamu politikaları oluşturulmasının önemini ve gereğini vurgulamaktadır.

Modern yaşam tarzlarıyla birlikte erkeklerin giderek babalık sorumluluklarından uzaklaştıkları bir tür patriarkal krize de şahit olunmaktadır. Babalık, anne-çocuk ilişkisinde olduğu gibi, biyolojik bağ açısından kolay belirlenebilir olmadığı için, erkekleri babalık sorumluluklarını üstlenmeye "ikna etmek" cinsiyet rejimlerinin en önemli stratejik sorunlarından biri haline gelmektedir.

Babalarıyla yakınlık kurmak, ona benzemek, onunla iletişimde ve yakın ilişkide bulunmak erkek çocuklar için son derece önemli bir gelişim sürecidir. Babayla özdeşleşme, erkek çocukların kimlik gelişiminde hayati bir önem taşımaktadır. Anneden farklı olarak baba dış dünyayı, gücü, rekabeti, iktidarı, macerayı, “erkek olmayı” ve "erkek gibi davranmayı” temsil etmektedir. Erkek çocuğun gelecekte bulunacağı dünyayı ve ortamı hazırlamak açısından baba figürü son derece önemlidir. Erkek çocuk babasıyla çatışarak, dövüşüp rekabet ederek kendini dış dünyaya ve gelecekteki rolüne hazırlamaktadır. Bu gibi çatışmaların, şefkat ve sevgi alışverişiyle dengelenerek yapılması, sağlıklı gelişmenin oldukça önemli bir parçasıdır. Ergenlik dönemindeki isyan ve kavgaları, erkek çocuğun kimlik geliştirme çabaları olarak görebilmek, bunlara izin verip sevgisini esirgememek, bir babanın çocuğuna gösterebileceği en büyük sevgi ve anlayış göstergesidir. İş yaşamı, ev geçindirme, ekonomik zorunluluklar, evden uzakta çalışma, toplum- 
da kendine bir yer edinme çabası ve sosyalleşme ihtiyaçları çoğunlukla babaların evde sadece simgesel olarak var olmasına neden olmaktadır. Babanın evde bulunmadığı veya çok az bulunduğu ailelerde babalar annenin ve çevrenin yaşattığı simgeler aracılığıyla tanınmakta; evde az görülen babanın kimliğini, annenin baba hakkındaki duygu ve düşünceleri oluşturmaktadır (Navaro, 2007, 153-154).

Babalarla çocukları arasındaki mesafe genellikle saygı ve itaat tutumuyla açıklanmaktadır. İtaat kültürünün babanın egemenliği için gerekli olduğu ve babanın çocuğuna yakınlaşmasını engelleyen etkenin, babanın sahip olduğu iktidar konumu olduğu belirtilmektedir. Örneğin çocuğunu uykusunda öpmek davranışı otoritenin zarar görmeyeceği bir zamanı seçmek olarak yorumlanabilmektedir. Anne-babaya saygısızlık ve itaatsizlikte bulunmanın en büyük günahlardan biri olarak kabul edildiği bir toplumda “itaat kültürü”nün egemen olması ve kaynağını dinden alması olağan sayılmalıdır. Otoritenin çocuk karşısında başvurduğu egemenlik kurma yollarından biri de yasaklama ve korkutmadır. İlk bakışta eğitim aracı gibi görünmekle birlikte aslında egemenlik kurmak ve sürdürmek içindir (Onur, 2005, 533-534). White (1994) babaların "babalık” kavramına yükledikleri anlamları ve "babalık" kavramına atfettikleri davranış ve alışkanlıkları, aslında kendi babalarıyla olan ilişkilerine dayanarak kurguladıklarını ortaya koymuștur.

Günümüzde teknolojik ve ekonomik alanlardaki sürekli ve hızlı gelişmeler aile yapısında ve aileyi oluşturanbireylerin görev ve sorumluluklarında değişmelere neden olmaktadır. Geleneksel geniş ailenin yerini anne, baba ve çocuklardan oluşan çekirdek aile yapısı almaktadır. Ekonomik koşulların ağırlaşması, kadınların eğitim düzeylerinin yükselmesi ve teknolojik gelişmeler her geçen gün kadın iş gücüne duyulan ihtiyacı arttırmakta, annenin çalışma yaşamına girmesi, aile içindebabanıngörev ve sorumluluklarında değişmelere neden olmaktadır. Bu değişmelere paralel olarak baba, ailenin gelirini sağlamanın yanı sıra çocukların bakım ve eğitimlerinde önemli bir rol oynamaya başlamaktadır (Çağdaş, 2003, 35). Booth'un (1998) da ifade ettiği gibi, erkeklerin baba ve koca olarak aile içi rolleri, ekonomik değişiklikler ve büyük tarihsel olaylar nedeniyle zaman içinde değişime uğramaktadır. Erkeklerin aile hayatına nasıl katıldığı ve bu katılımın ne gibi farklılıklar yarattığı konusunda koca ve baba rollerindeki davranışları oldukça önemlidir. Erkeklerin aile içi rolleri, ırk ve sınıf bağlamında dönemlerin ekonomik ve kültürel iklimine göre meydana gelmektedir (Akt. Eken, 2010, 38).

Özellikle 70’li yıllarda toplumsal yapıdaki değişmelerle babanın aile içindeki rolü ve çocuğun üzerindeki etkisi yeniden sorgulanmaya başlanmıştır. Daha önceleri kadın ve erkeğin rolleri, dolayısıyla annelik ve babalık birbirinden çok katı sınırlarla ayrılırken, o dönemlerde kadınlık/ erkeklik, karı/kocalık, annelik/babalık rolleri temeldeki farklılıklarını korumakla birlikte eskiye oranla birbirlerine daha fazla yakınlaşmaya başlamıştır. Hem kadınlar hem de erkekler, erkeklerin çocuk bakması, ev işi yapması fikrine alışmışlardır. 30-40 yıl öncesinde babanın bebeğini biberonla beslemesini, altını temizlemesini düşünmek bile garip, sıra dışı karşılanırken bugün birçok baba çok doğal bir şekilde bunları yapmakta, yapmasa bile en azından garip karşılanmamaktadır. Toplumun değer yargıları, annelik ve babalık rolü tanımlamaları değiştikçe iyi bir anne ya da babanın anlamı da değişmektedir. ABD'de gerçekleştirilen çalışmalara bakıldığında Amerikan toplumunda 18. yüzyıldan günümüze babalık kavramının dört aşamadan geçtiği görülmektedir. Bu aşamalar sırasıyla şunlardır (Güngörmüş Özkardeş, 2010, 17-24):

\section{- Ahlak öğretmeni babalar}

18. yüzyıl ile 19. yüzyılın başlarına kadar olan dönemde babaların en önemli görevi, çocuklarına ahlaklı olmayı öğretmek ve onlarda gördükleri hataları düzeltmekti. Bu dönemde çocukların İncil'in öğretilerine uygun değerlerle büyütülmesinden öncelikli olarak babalar sorumluydu. 
Babalar çocukların evlenme kararlarında anahtar rolü üstlenmek; oğluna meslek seçimi konusunda rehberlik etmek ve kendisi okur-yazarsa çocuklarına okuma-yazma öğretmekle görevliydi. Babaların çocuklarına okuma-yazma öğretmelerinin asıl nedeniyse eğitim değil, İncil’i okumak ve anlamaktı. Bu dönemde kadınlar erkeklere oranla daha çok duygularıyla hareket eden, mantıksız düşünen ve daha yanlış yola düşebilecek bireyler; çocuklarsa doğuştan günahkâr olarak algılanmaktaydı. Kadınların ve çocukların denetimi erkeğe aitti. Evliliğin sona ermesi durumunda çocuğun bakımı ve sorumluluğu da babaya verilmekteydi. Kısacası bu dönemde iyi baba algısı, iyi bir Hıristiyan olarak yaşayan, kutsal kitap doğrultusunda çocuğunu iyi bir şekilde bilgilendiren ve çocuklarını ahlaklı bireyler olarak yetiştiren kişi olarak belirmiştir.

- Evinin ekmeğini kazanan babalar (19. yüzyıl başları - 20. yüzyıl ortaları)

19. yüzyılda Sanayi Devrimi sonrasında erkekler evlerinden uzakta daha uzun saatler çalışmaya başlayınca anneler, babaların sorumluluklarını da üstlenmiş̧lerdir. Sanayi Devrimi’nin ortalarında baba ahlak öğretmeni olmaktan çıkarak evin ekmeğini kazanan kişi kimliğine bürünmüştür. Çocukları ilgilendiren konularda tek söz sahibi artık baba değildir. Çocuklarla ilgili konularda hem anne hem de baba söz hakkına sahiptir. Bu değişime paralel olarak kadınların saflığı, masumiyeti vurgulanmaya başlanmış ve kadınların saflığının çocukların yetiştirilmesine daha uygun olduğu görüşü kabul edilmiştir.

- Çocuğun cinsel kimliğini kazanmasına yardımcı olan babalar(1940 ile 1965 yılları arası) 1940 ile 1965 yılları arasında yaşanan savaşlar, babalık kavramına yeni bir tanım getirmiştir. Savaşa giden babaların birçoğunun dönmemesi sonucunda çalışan kadın sayısı artmış ve kadınlar erkeklerden bağımsız olarak yaşamayı öğrenmek zorunda kalmışlardır. Bu dönemde boşanma sayılarında da önemli bir artış görülmüştür. Bu dönemde babanın varlığından çok yokluğunun ya da evde olup aile içi kararlarda söz sahibi olmayan babaların çocuklarını nasıl etkileyebileceği sorgulanır olmuştur. Ahlak öğretmeni olarak kabul gördüğü dönemden sonra babaların önemi yeniden vurgulanmaya başlanmıştır.

Babalar ahlak öğretmeni ve evin ekmeğini kazanma kimliğine sahip olmalarının yanında özellikle oğullarının cinsel kimliğini kazanmalarında da önemli bir role sahiptir. Bu dönemde babaların çocuklarının eğitimine katılımı desteklenmiş ancak annelik ve babalık arasında kesin bir ayrım da söz konusu olmuştur. Çocukların eğitiminde babanın emredici, annenin ifade edici bir rolü olduğu kabul edilmiştir. Baba daha çok evin dışında çalışmakta, toplumsal olaylar ve politikayla ilgilenmekte, çocuk bakımına daha az katılmaktaydı. Annenin üstlendiği rolse aile içindeki olaylarda karşılaşılan stresle baş edebilmeyi sağlamak, aile üyeleri arasındaki ilişsileri düzenlemek, duygusal destek sağlamak ve baba-çocuk arasındaki ilişkide arabuluculuk yapmak olarak belirlenmişti.

- Çocuklarma bakan babalar (1965’ten günümüze)

1970’li yıllarla birlikte babaların çocuklarının bakımına aktif bir şekilde katıldıkları gözlenmeye başlamıştır. Bu dönemin yeni baba modeli geçmiştekilerden oldukça farklıdır. Yeni baba doğuma giren, bebeklik dönemlerinde de çocuklarıyla ilgilenen, yalnızca oyun oynamakla yetinmeyen, çocuk bakımına daha aktif olarak katılan ve oğullarıyla olduğu kadar kız çocuklarıyla da ilgilenen bir baba modelidir. Özellikle bu dönemde Amerika'da babalarla ilgili araştırmaların sayısı oldukça artmıştır.

Almanya’ya bakıldığında Federal Aile, Yaşıllar, Kadın ve Gençlik Bakanlığı (Bundesministerium für Familie, Senioren, Frauen und Jugend) 1990’lı yılların sonlarından itibaren Alman toplumunda ailenin ve aile içinde toplumsal cinsiyet rollerinin dönüşümü ve erkeklerin iş ve aile arasında daha iyi bir denge kurmalarının koşullarının yaratılarak onların aile içinde daha fazla sorumluluk alabilmelerini sağlamak için devlet tarafından yapılması gereken değişimlerin 
saptanması için birçok araştırma (Bundesministerium Familie, Senioren, Frauen und Jugend 1998; Wettbewerbstärke und bessere Vereinbarkeit von Familie und Beruf - kein WiderspruchFlexible Arbeitszeiten in Klein- und Mittelbetrieben-. Stuttgart; Berlin; Köln: Kohlhammer; Bundesministerium Familie, Senioren, Frauen und Jugend, 2006; Facetten der Vaterschaft Perspektiven einer innovativen Väterpolitik; Bundesministerium Familie, Senioren, Frauen und Jugend, 2008; Evaluation des Gesetzes zum elterngeld und zur Elternzeit; Bundesministerium Familie, Senioren, Frauen und Jugend, 2011; Vaterschaft und Elternzeit. Eine interdisziplinäre Literaturstudie zur Frage der Bedeutung der Vater-Kind-Beziehung für eine gedeihliche Entwicklung der Kinder sowie den Zusammenhalt in der Familie. Daha ayrıntılı bilgi için bakınız: http://www.bmfsfj.de/) yapmakta ya da yaptırmaktadır. Almanya'da Janzen (2010) yaptığı alan çalışmasının sonuçlarını değerlendirirken, 19. yüzyılın sonunda Sanayi Devrimi sonrasında sanayileşmiş ülkelerde babaların dışarıda çalışmaları nedeniyle aileyle olan bağlarının zayıfladığını ancak günümüzde ailelerde yeni bir gelişmenin gözlendiğini, genç erkeklerin kendi babalık rollerini irdelediklerini ve daha aktif bir babalık özlemi içinde olduklarını ifade etmektedir. Ancak toplumsal, siyasal ve ekonomik koşullardan dolayı babaların bu özlemlerini gideremediklerini, erkeklerin ailede daha etkin bir rol oynayabilmeleri için sözkonusu koşullarda değişimin gerektiğini de eklemektedir.

Karin Böllert ve Corinna Peter'in editörlüğünde 2012'de Almanya'da yayınlanmış olan Anne + Baba $=$ Ebeveynler? Toplumsal Değişme, Ebeveyn Rolleri ve Sosyal Hizmet başlıklı çalışmadaki bölümünde, adı geçen ülkelerde erkeklik ve babalık çalışmalarının önde gelen isimlerinden Michael Meuser (2012, 63-80) dönüşüm içinde olan babalığa ışık tutmakta ve genel sorunlar, alternatifler ve çelişkilerle ilgili saptamalarda bulunmaktadır. Babalık anlayışının gelişiminin tarihine göz attıktan sonra Meuser, cinsiyetler arası ilişkilerdeki değişime, endüstri toplumundan hizmet toplumuna geçişe ve babalar için "olası babalık" biçiminde birçok sorun ve alternatife yol açan bireyselleşmenin toplumsal değişimine değinmektedir. Yazar ayrıca zor olarak nitelendirdiği babalık söylemi ile babalık pratiği ilişkisini çözümlemekte ve son olarak eylemleriyle "yeni baba” imajına uyan babalara göz atmaktadır. Kaila-Behm ve VehviläinenJulkunen (2000) tarafından gerçekleştirilen bir başka çalışmadaysa Finlandiya'da 71 babayla yapılan görüşme ve 175 sağlık çalışanının yazdığı notlara dayanılarak, katılımcılar için babalığın salt izleyici, eşe destek, eş ve aile reisi olarak dört temel role sahip olduğunu ortaya koymuştur.

18. yüzyıl ile 19. yüzyılın başlarına kadar olan dönemde ahlak öğretmeni olan baba, Sanayi Devrimi'nin ortalarında evin ekmeğini kazanan kişiye dönüşmüştür. Günümüz babalarının bu iki görevi hala sürmekle birlikte, çocuğun bakımı ve eğitiminde daha aktif bir rol üstlenmeye başlamışlardır. Bu değişim elbette ki, sadece Amerikan toplumuna özgü değildir. İngiltere'de 1940’dan 1980 yılına kadar annelere çocuk bakımına ilişkin bir anket uygulanmıştır. Bu araştırmanın bulgularına göre babalar, çocuk bakımı konusunda giderek artan bir biçimde aktif rol almaktadırlar. Türk toplumuna bakıldığında geçmiş̧en günümüze baba kavramının benzer değişimler geçirdiğini belirtmek yanlış olmayacaktır. Türk edebiyatının gerçek anlamda ilk popüler yazarı olan Ahmet Mithat, çocuğun eğitiminden babanın sorumlu olduğunu çünkü babanın hem eğitiminin hem de doğasının anneden üstün olduğunu, annenin sadece üç yaşına kadar önemli olduğunu belirtmiştir. Bununla birlikte, Namık Kemal de benzer düşüncededir. 1950’li yıllardan başlayarak hızlı değişimlerin yaşandığı Türkiye’de çekirdek aile yapılarının ve çalışan kadın sayısının artması baba-çocuk ilişkisini ve babalık kavramının da değişimine yol açmıştır. Türkiye’de aile-çocuk ilişkisi konusunda fazla sayıda çalışma olmasına rağmen, bunların çok azı baba-çocuk ilişkisi ve babalık üzerine odaklanmaktadır (Güngörmüş-Özkardeş, 2010, 24). 
Yakın zamana kadar baba-bebek ilişkisi ve bu ilişkinin değeri pek fazla önemsenmemiştir. Özellikle bebeklerin ilk yıllardaki bakımının anne tarafından yapıldığı ve annenin zamanının çok büyük bir kısmının bebeğiyle geçmesi nedeniyle yalnızca anne-bebek bağının önemli olduğu kabul edilmiştir. Ancak bu görüş değişmektedir. Babaların ve bebeklerin aralarında bir bağlanma yaşadıklarını ve babaların da bebeklerin gelişiminde önemli rol oynadıklarını gösteren araştırma bulguları her geçen gün artmaktadır (Gander, \& Gardiner, 1993’ten akt. Çağdaş, 2003, 35). Yapılan araştırmalardan elde edilen bulgular, babaların da anneler kadar bebeklerine ilgi gösterdiklerini ve bu konuda anneden çok farklı olmadıklarını ortaya koymaktadır. Babaların sosyal ve ekonomik uygulamalar sonucu aile içinde farklı roller üstlenmesi, çocuk bakımı konusunda yetersiz olduklarını göstermemektedir. Bulgular, babaların da anneler kadar çocuklarının psiko-sosyal ve zihinsel gelişimlerinde etkin rol oynayabileceklerinin altını çizmektedir (Dönmezer, 1999'dan akt. Çağdaş, 2003, 36). Bunlara ek olarak, Erikson'un çalışmalarına atıfta bulunarak babalığın toplumsal konumuna odaklanan Snarey’e (1993) göre, baba olan erkekler toplumda daha etkin rol almaya başlamakta ve kendilerinden genç olanlara rehberlik etme rolünü üstlenmektedirler.

Güngörmüş (1998) babanın çocuğu üzerindeki etkilerini dolaylı ve dolaysız etkiler olmak üzere iki grupta toplamaktadır. Ailenin gelirini tümüyle ya da eşiyle birlikte karşılaması ve eşine karşı davranışları, eşiyle ilişki biçimi babanın çocuğu üzerindeki dolaylı etkileridir. Anne-baba arasındaki iyi ilişkiler, anne-çocuk arasındaki ilişkiyi de olumlu yönde etkilemektedir. Babanın varlığı ve desteği anne-çocuk ilişkisinin daha sağlıklı olmasını sağlamaktadır. Eğer anne-baba arasındaki ilişki sağlıklı değilse, anne bu boşluğu doldurmak için bütün ilgisini çocuğa yöneltip aşırı koruyucu bir tutum geliştirerek çocuğun bağımsız bir kişilik geliştirmesine engel olabilmektedir. Babanın çocuğuna dokunması, konuşması, oynaması ve çocuğuyla ilgili çeşitli kararlara aktif olarak katılmasıysa babanın çocuğu üzerindeki dolaysız etkileri olarak ifade edilmektedir (Akt. Çağdaş, 2003, 38).

Her baba çocuk bakımına aynı derecede katılmamaktadır. Babaların bir kısmı, çocuklarının her türlü faaliyetiyle yakından ilgilenirken, diğer bir kısmı daha sınırlı bir katılım gösterebilmektedir. Baba katılımını hangi unsurların etkilediğini inceleyen araştırmalar başlıca beş etkenden söz etmektedir. Bunlar; evlilikten memnun olma, annenin ev dışında çalışıp çalışmaması, baba rolünün nasıl algılandığı, baba olmanın zamanlaması ve çocuğun cinsiyeti ve cinsiyet rolünün gelişimi olarak ifade edilmektedir (Atmaca-Koçak, 2004, 7-9).

\section{- Evlilikten memnun olma}

Araştırmalar evlilikten memnun olmanın ve evlilikteki uyumun, erkeklerin bir baba olarak nasıl davrandığı yönünde önemli ölçüde etkili olduğunu göstermektedir (Perry-Jenkins, Huston, \& McHale, 1987; Levy-Shiff, \& Israelashvilli, 1988; Cox, Owen, Lewis, \& Henderson, 1989; Crouter, Doherty, Kouneski, \& Erickson, 1998;). Bir başka araştırma (Cox vd., 1989) eşleriyle yakın ilişkileri olan erkeklerin çocuklara ve bir baba olarak kendilerine yönelik tutumlarının pozitif yönde olduğunu ortaya koymaktadır.

\section{- Annenin ev dışında çalışıp çalışmaması}

Annenin ev dışında çalışmasının çocuklar üzerindeki etkisini değerlendirmek amacıyla gerçekleştirilen bazı araştırmalar, babanın eve giren tek geliri sağladığı ailelerle hem anne hem de babanın çalıştığı aileler arasında baba katılımında bir fark olup olmadığını inceleyerek, annenin ev dışında çalışmasının baba katılımını etkilediği sonucuna ulaşmışlardır (Radin, \& HaroldGoldsmith, 1989; Brayfield, 1995; Coltrane, 1995; Marsiglio, 1995). Anne ve babanın her ikisinin de çalışığı çift gelirli ailelerde, babaların çocuk bakımıyla daha fazla ilgilendikleri gözlenmektedir. 


\section{- Baba rolünün nasıl algılandığı}

Bir erkeğin kendisini baba olarak nasıl algıladığı, bu role kendini ne denli yakın hissettiği de çocuk bakımına katılımı açısından önem taşımaktadır. Bazı araştırmalar (Levy-Shiff, \& Israelashvilli, 1988; Doherty vd., 1998) babalığa atfedilen anlamların özellikle ağırlık kazandığını, baba olmak olumlu ve anlamlı bir şey olarak görüldüğünde babanın katılım düzeyinin artma eğiliminde olduğunu ortaya koymaktadır.

\section{- Baba olmanın zamanlaması}

Erken yaşta, henüz kendisini hazır hissetmeden baba olmak bir krizle sonuçlanabilmekte ve erkek, planlanmamış çocuğu geleceğinde bir engel olarak görebilmektedir. Yapılan bir araştırma (Cabrera, Tamis-LeMonda, Bradley, Hofferth, \& Lamb, 2000) planlanmış bir hamileliğin olumlu ebeveynlikle sonuçlandığını ortaya koymaktadır.

\section{- Çocuğun cinsiyeti ve cinsiyet rolünün gelişimi}

Çocuğun cinsiyeti de babanın katılım düzeyini etkileyen bir diğer unsur olarak karşımıza çıkmaktadır. Kız çocukları annelerini örnek alırken, erkek çocuklar babalarına ihtiyaç duymaktadır. Marsiglio (1991) araştırmasında, babalarının kız çocuklarına oranla erkek çocuklarıyla daha fazla iletişim kurduklarını; dinlenme ve proje faaliyetlerine daha fazla zaman ayırdıklarını; erkek çocuklarıyla daha fazla oynadıklarını ortaya koymaktadır. Bir diğer araştırma, Baruch ve Barnett (1987)'in Kuzey Amerika orta sınıfından 5 ile 10 yaşındaki çocuklardan oluşan örneklem çerçevesinde benzer sonuçlara ulaşmaktadır. Babaların erkek çocuklarının bakımına ve onlarla oynamaya daha fazla zaman ayırdıklarını ortaya koymaktadır.

Türkiye'de baba-çocuk ilişkisine yönelik gerçekleştirilen üç temel çalışma bulunmaktadır (Güngörmüş-Özkardeş, 2010, 24-27). Bunlardan ilki, Güngörmüş-Özkardeş, \& Arkonaç (1998) tarafından yürütülmüştür. Çalışma kapsamında İstanbul'da yaşayan ilkokul ve yüksekokul mezunu olan iki grupla yapılan görüşmelerde babalara kendilerini nasıl bir baba olarak gördükleri, ideal bir babanın ve kendilerinden farklı bir babanın özelliklerini nasıl tanımladıkları sorulmuştur. Araştırma bulgularına göre babaların eğitim düzeyi arttıkça çocuğuyla ilgili işlere doğrudan katılmaya daha yatkın ve daha demokratik bir tutum benimsedikleri görülmüştür. Bununla birlikte ilkokul mezunu babalar kendileriyle ideal baba özellikleri arasında fark görmezken, üniversite mezunu babalar kendi özelliklerinden farklı olarak ideal babanın ailesine daha fazla zaman ayırmak, çocuğa güven vermek, onu desteklemek ve ona hoşgörülü yaklaşmak gibi özellikleri olduğunu belirtmişlerdir. Sonuç olarak eğitim düzeyi arttıkça babalar çocuklarının yaşamında daha aktif olmaları gerektiğinin farkına varmakta ancak çeşitli sebeplerle bunu uygulayamamaktadırlar. İlkokul mezunu babalar evin ekmeğini kazanan, evin bütün gereksinimlerini karşılayan ve çocuklarını dürüst ve terbiyeli yetiştirmeye çalışan kişiyken, yüksekokul mezunu babalar çocukların problemlerini paylaşan, onlara yakın olan, onların yarınlarını düşünen, onlar için çalışan ve eşine yardımcı olan kişilerdir.

Bir diğeri, Evans’ın (1997) İstanbul ili içerisinde düşük sosyo-ekonomik düzeye sahip ilkokul mezunu kişilerin kendi babalık rollerine yönelik tutum ve katılımlarını incelemek amacıyla 60 babayla gerçekleştirdiği çalışmasıdır. Evans babaların davranışlarını karşılaştırarak tutumların ve davranışların üç boyutunu inceleyerek şu bulguları elde etmiştir: Babalar çocukların fiziksel bakımını annelerin işi olarak görürken, kendilerine düşen görevleri çocuğa zihinsel beceriler öğretmek, eğitimi hakkında karar vermek, bakımı için gerekli olan parayı kazanmak olarak ifade etmişlerdir. Çocuğun toplumsal değerleri öğrenmesine yönelik görevlerse eşler arasında paylaşılmıştır. Babalar, babalık rollerine ilişkin en önemli buldukları noktaları maddi yönden çocuğa bakabilmek ve sevgiyle şefkat göstermek olarak belirtmişlerdir. GüngörmüşÖzkardeş, \& Arkonaç (1998) ve Evans (1997) tarafından gerçekleştirilen her iki çalışmada da 
ilkokul mezunu babaların ifadelerinin benzerliği dikkat çekicidir. Gelir seviyesi orta ve alt düzeylere geriledikçe, kadınların erkeğin en önemli görevinin aileye iyi bir yaşam standardı sağlamak için çalışması olduğunu düşündükleri gözlenmektedir. Ev işleri ve çocuk bakımında babanın herhangi bir sorumluluk almasının beklenmediği ancak babaların çocuğun eğitimine katılmaları ve ahlaki açıdan bir rehber olarak yardımcı olmaları gerektiği düşünülmektedir. Turan ve arkadaşları (2001) tarafından gerçekleştirilen çalışmaysa anne adayları ve eşleriyle yürütülmüştür. Düşük ve alt-orta sosyo-ekonomik düzeyden gelen ailelerle yapılan bu çalışmada eşler erkeğin en önemli görevinin iyi bir yaşam standardı sağlamak için çalışması olduğunu belirtmişlerdir. Güngörmüş-Özkardeş, \& Arkonaç (1998), Evans (1997), Turan ve arkadaşları (2001) tarafından gerçekleştirilen her üç çalışmada da babaların en önemli görevinin ailenin geçimini sağlamak olarak algılandığı sonucuna varılmaktadır. Eğitim düzeylerinin yükselişine bağlı olarak babalar çocuklarıyla daha çok ilgilenme, paylaşımda bulunma gibi etkinlikleri de kendi sorumlulukları olarak algılamaktadırlar.

Türk toplumunun kültürel yapısı içinde babaların rollerini, geçmişten günümüze ne tür değişimler geçirdiğini, nelerden etkilendiğini, neleri etkilediğini ve ilerleyen dönemlerde nasıl biçimleneceğini ortaya koyabilmek için çok daha fazla sayıda çalışmaya ihtiyaç duyulmaktadır (Güngörmüş-Özkardeş, 2010, 27). Bu bağlamda Bağlı ve Sevim’in (2007) medya aracılığıyla aktarılan kültürün anne-babalığa nasıl yaklaştığını, medyada anne-babalıkla ilgili ne gibi mesajların verildiğini, anne-baba kimliğinin nasıl değerlendirildiğini, annelik ve babalık rollerine ve çocuk yetiştirmeye ilişkin nelerin vurgulandığını saptamak amacıyla gerçekleştirdikleri çalışmaları da oldukça önemlidir. Bağlı ve Sevim bu çalışmada "Ailem ve Ben, Anneyiz Biz, Aile ve Çocuk, Parents, Bebeğim ve Biz, Çocuğum ve Ben, Anne \& Trends” dergilerinin 2005 yılında yayınlanmış olan sayılarından toplam 14 dergiyi incelemişlerdir. İlk olarak bu dergilerin demokratik anne-babalığı savunduğu ancak bu durumu çoğu zaman izin verici anne-babalıkla karıştırdıkları görülmektedir. Çalışmada, annelik konusunda modern düşüncelerle geleneksel anlayışların iç içe geçtiği; annelikle karşılaştırıldığında baba olmanın ve babalıkla ilişkili konuların dergilerde daha az kapsamlı bir biçimde yer aldığı da görülmektedir. Baba olmak, babalık rolü ve sorumluluğu konusunda dergilerde daha az sayıda yazı ve bölüm yer almakta, mevcut yazı ve bölümlerin kapsamı da dar olmaktadır. Göze çarpan bir diğer nokta da, dergilerin annelerin çalışmasıyla ilgili tutumlarıdır. Annenin çalışması kabul edilmekte ancak çocuğun bakımında asıl sorumlunun anne olduğu vurgulanmaktadır. Bağlı ve Sevim’e göre dergiler, modern babalıkla ilgili konulara değinmekte tereddüt etmekte ve kaygı duymaktadır. Dergilerin babalar ve babalıkla ilgili içeriği göz önüne alındığında şu mesajlar dikkati çekmektedir:

- Babalar da hamilelik belirtileri (Couvade (Sempatik Gebelik) Sendromu, ilk olarak 17. yüzyılda French Basque tarafından tanımlanmıştır. Fransızca "couver”dan türetilen kelime, "yumurtadan civciv çıkarmak" ya da "kuluçkaya yatmak" anlamına gelmektedir. Couvade sendromu eşleri gebe kalan erkeklerin, kısa bir süre sonra gebelik semptomlarını yaşamasıdır. Bu semptomlar; mide ve bağırsak sistemi hastalıkları, karın büyümesi, iştahta değişme, kokuya hassasiyet, sırt ağrıları, bacak krampları, halsizlik, uyku yakınmaları, diş ağrısı, deride isilik, bayılma ve kilo almadır. Gebeliğin bu sempatik semptomları Trethowan, \& Conlon, 1965 tarafından Couvade sendromu olarak adlandırılmıștır. Couvade sendromunun psikolojik semptomları ise anksiyete, depresyon, stres, sinirlilik, ruhsal çalkalanma, vücut bütünlüğü ile ilgili endişe ve vücudun algılanmasında yaşanan değişikliklerdir. Couvade sendromu dışarıdan birinin fark edemeyeceği kadar hafif seyredebileceği gibi gerçek bir ruhsal bozukluk görüntüsü de yaratabilmektedir) gösterirler.

- Babalar anneye yardımcı olurlar.

- Baba olmak korkutucudur. 
- Baba (kötü bir) oyun arkadaşıdır.

- Babalık işlevseldir (Bağll, \& Sevim, 2007, 150-154).

Bir başka çalışmadaysa Sancar (2009), farklı babalık modellerinin farklı erkeklik modellerine tekabül ettiğini belirtmektedir. Sancar’a göre, farklı erkeklik ve babalık modelleri her şeyden önce kır-kent ayrımı ve sınıfsal farkları oluşturan eğitim ve aile biçimlerine dayalı kültürel sermayeyle ilişkilidir. Farklı babalık modellerini tanımlarken karşımıza çıkan egemen babalık modeli, geçimi sağlayan aile babasıdır. Bu babalık modelinin oluşum, gelişim ve yenilenme rotalarına bakıldığında, toprağa bağlı yaşamdan kentsel yaşam biçimine göçün en uygun toplumsal bağlamlardan birini oluşturduğu görülmektedir. Sancar, Türkiye'de en yaygın babalık biçimini erkeğin geçim sorumluluğunu büyük ölçüde tek başına üstlendiği, kadınların sadece ev işi yaptıkları, kız çocukların okutulmakla birlikte erkek çocuklarla eşit görülmediği “modernleşmiş" aile babalı̆̆g şeklinde ifade etmektedir.

Babalık, yasaların gözünde çocuklarına bakmakla ve eğitmekle yükümlü vatandaş; velayet ve vesayet sahibi erkek demektir. Babalık aile, piyasa ve devlet arasındaki ilişkilerle şekillenen ve bütün bu alanları birbirine bağlayan; ailede geçimi sağlayan, piyasada çalışan ve devletin karşısında aile reisi olarak konumlanan bir toplumsal pratik, bir dolayım konumudur. Türkiye'de erkeklerin "aile reisi” olarak sahip oldukları ayrıcalıklar ve para kazanan kişi olarak ellerinde tuttukları karar verme yetkisi yakın zamanlarda Medeni Kanun'da yapılan değişikliklerle hukuken ortadan kaldırılmıştır. Evlilik ve aile kurumu içindeki kadın ve erkeğe sorumluluklar ve haklar eşit bir şekilde dağıtılmıştır. Toplumsal yapıdaki bu değişmeler yasal düzenlemelerde de bir karşılık bulmaya başlamıştır. Örneğin İsveç yasal düzenlemelerle babanın da anne gibi uzun süreli doğum izni kullanabilmesine imkân sağlamıştır. Türkiye’de de bu konuyla ilgili yasal düzenlemeler yapılmaya başlanmıştır (Güngörmüş-Özkardeş, 2010, 18).

Possinger (2013) Alman toplumunda "yeni babalar” tartışmalarının özellikle 2009 yllında Federal Hükümetin çıkardığı "Federal Ebeveynlik Parası” yasası kapsamındaki "babalık aylı̆̆ı” olgusuyla birlikte yoğunlaştığına dikkat çekmektedir. "Yeni baba" ile kastedilen devletin sağladığı bu olanaktan yararlanarak çocuklarının bakımı için mesleğini ikinci plana atmayı göze alıp, aktif babalık yapan babalardır. Bu babaların oranı 2011 yılı itibariyle \% 25’tir (Alman İstatistik Enstitüsü). Possinger'in belirlemelerine göre yine de bu durumu geleneksel anne ve baba rollerine ilişkin yaklaşımların tamamen dönüştüğüne ilişkin bir gösterge olarak kabul etmek için henüz çok erkendir.

Popenoe’ye (1999) göre evlenme oranlarının düşmesi, boşanmaların, tek ebeveynli yaşam düzenlemelerinin ve evlilik dışı doğumların artması babalık kurumunu toplumsal olarak zayıflatan güncel gelişmelerdir. Bununla birlikte, yeni üreme teknolojilerinin gelişmesiyle babalığın biyolojik bir olgu olarak da zayıfladığını söylemek mümkündür. Bütün bunlar, babalık kurumunun toplumsal bir kriz yaşamakta olduğunu göstermektedir (Akt. Bağlı, \& Sevim, 2007, 156157). Toplumun değer yargıları, geleneksel cinsiyet rolleri ve dolayısıyla annelik ve babalık rollerine ilişkin tanımlamalar değiştikçe iyi bir anne ya da baba olmanın ve bunun getirdiği gerekliliklerin de anlamı değişmektedir. Günümüzde farklı erkeklik ve babalık modellerinin varlığı kabul edilmekle birlikte, egemen olan babalık modeli evin geçimini sağlayan aile babasıdır. Ancak eğitim ve gelir düzeyi gibi faktörlerin yükselişine bağlı olarak ev işleri, çocuk bakımı gibi konularda eşlerinin sorumluluğunu paylaşan babaların sayısı da her geçen gün artmaktadır.

Türkiye'de annelik ve babalık üzerine yapılan araştırmaların özellikle gelişim psikolojisi ve sosyal psikoloji alanlarında 1970’li yıllardan itibaren giderek arttığı görülmektedir. Annelik ve babalık psikolojinin en temel konularından biri olmakla birlikte biyoloji, sosyoloji, hukuk, tıp, antropoloji ve tarih gibi pek çok bilimsel disiplinin de ilgilendiği çok yönlü bir konudur. Batıda 
yüz yılı aşkın bir süredir bilimsel olarak incelenmekte olan annelik ve babalık, büyük ölçüde kültür tarafından şekillenen bir olgudur. Bununla birlikte günümüzde toplumların yaşamakta olduğu hızlı değişim sürecinin ve genetik, tıp gibi bilimsel disiplinlerdeki gelişmelerin bir sonucu olarak annelik ve babalık niteliksel anlamda değişmekte ve çeşitlenmektedir. Küreselleşen ve diğer kültürlerin etkilerine daha açık bir hale gelen günümüz toplumlarında geleneksel, kültürel inanç ve değerlerle temellenmiş olan annelik-babalıkla modern annelik-babalık uygulamalarının iç içe geçtiği görülmektedir (Sayıl, \& Yağmurlu, 2012, 15-16). Ataca (2006) tarafından gerçekleştirilen çalışmadaysa, Türkiye'de nüfusun \% 70'inin kentlerde yaşamasına karşın geleneksel değerlerin ve uygulamaların sürdüğü; toplumda önemli dönüşümler olmasına karşın geleneksel tutumların ve değerlerin aynı hızla değişmediği; kültürün ataerkil ve yetkeci niteliğini hala koruduğu sonucuna ulaşılmıştır. Türk aile yapısı içinde çocuk yetiştirme uygulamalarında süreklilik ve değişimin bir arada görüldüğünün altı çizilmiştir. Anne ve babaların yetkeci denetiminin yanı sıra, gün geçtikçe artan ölçüde ödül ve ikna gibi tekniklerin de yer alması bunun tipik bir örneğidir. En önemlisi de artık gelenekselle modern arasındaki ikilemin farkında olunmasıdır (Akt. Onur, 2012, 52).

Annelik ve babalığı, "amaç ve davranışları toplumsal ve kültürel benzerlikler gösteren; aynı bağlamda öğrenilen, sergilenen ve değerlendirilen tutum ve davranışlar” olarak tanımlayan Baydar, Akçınar ve İmer (2012) Türkiye'de annelik ve babalığa ilişkin tutum ve davranışları belirleyen etkenler konusunda gerçekleştirilen çalışmaların yetersiz olduğunu ve konuyla ilgili araştırmalara gerek duyulduğunu belirtmişlerdir. Benzer şekilde Güngörmüş-Özkardeş (2010) de, Türkiye'de baba-çocuk ilişkisini irdeleyen yeterli sayıda çalışma bulunmadığını ve değişen dünya koşullarında dönüşen baba figürünün önemini belirtmektedir. Çocuklar söz konusu olduğunda çoğunlukla anne-çocuk arasındaki ilişki üzerinde durulduğunu; bu ilişkinin anne ve çocuk açısından son derece önemli olduğunu ve babanın bu ilişkide neredeyse yok sayıldğını da vurgulayan Güngörmüş-Özkardeş, Türk toplumunun kültürel yapısı içinde babaların rollerini, geçmişten günümüze ne tür değişimler geçirdiğini, nelerden etkilendiğini, neleri etkilediğini ve ilerleyen dönemlerde nasıl biçimleneceğini ortaya koyabilmek için çok daha fazla sayıda çalışmaya ihtiyaç duyulduğunun altını çizmektedir.

\section{Günümüzde Erkeklerin Gözünden Babalık ve Aile: Alan Araștırması}

Bireyin objelere karşı geliştirdiği bir istenç, yaşantı, düşünce, duygu, inanç, değer ve değer yargılarıyla yakından ilgili olan bir zihinsel hazırlık olarak tanımlanan tutum, etkileşim sonucu ortaya çıkmaktadır. Tutum, bireyin kişi veya olgu karşısındaki davranışının özetidir. Tutumun oluşumuyla davranışın oluşumu arasında bir paralellik bulunmaktadır (Silah, 2005, 307-309). Tolan ve arkadaşlarına (1985) göre tutumun ölçülmesi bireyin bir nesneye ya da görüşe karşı hangi konumda olduğunun belirlenmesidir. Başka bir ifadeyle tutum, tümüyle benimsenen ya da tümden karşı çıkılan iki boyut arasındaki bir noktada yer alan derecedir. Tutumların ölçülebilmesi için önce tutumun varlığının araştırılması, bilinmesi ve bireyin davranışlarının gözlenmesi gerekmektedir. Tutum, davranışın gerisinde bulunan zihinsel bir hazırlık olduğundan dolaylı yoldan yani bireyin tutum gerçeğindeki önermelere verdiği cevaplara bakılarak ölçülebilmektedir. Tutum ölçeğinin, ölçme araçlarının taşıdığı teknik özelliklere sahip olması gerekmektedir. Her şeyden önce bir tutum ölçeği geçerli ve güvenilir olmalıdır. Ölçmede geçerlik; tutum ölçeğinin ölçmek istediğinin, amacına uygun olarak ölçmesi, ölçülecek özellikler arasına başka özelliklerin karıştırılmaması yani neyi, ne ölçüde ölçme gücüne sahip olduğudur (Akt. Silah, 2005, 316).

Bireylerin tutumlarını doğrudan gözlemlemenin imkânsızlığı nedeniyle Thurstone (1929) tutumların sözel bir ifadesi olan kanılar aracılığıyla ölçülebileceğini ifade etmektedir. Bazıla- 
rıysa kanıların her zaman tutumları ifade etmediklerini, bireyin söyledikleriyle davranışlarının farklı olabileceğini vurgulamaktadır. Bununla birlikte bireylerin davranışlarının, bireylerin kendilerine özgü tutumlarından kaynaklandığı kanısı çok yaygındır. Tutumların ölçülmesi bu temele dayanmaktadır. Zaman içinde Thurstone ölçeğinin uygulama güçlüğü nedeniyle Likert ve arkadaşları (1932) tarafından Likert ölçeği geliştirilmiştir. Likert ölçeği hazırlanması ve uygulaması kolay olduğu için en çok kullanılan ölçeklerden birisidir. Diğer ölçeklere oranla Likert ölçeğinin geçerlik ve güvenirliğinin oldukça yüksek olduğu kabul edilmektedir. Likert ölçeğinde katılımcılara çeşitli ifadeler yöneltilmekte ve bu ifadelere katılıp katılmama derecelerini belirtmeleri istenmektedir. Likert ölçeği bireylerin tutum ve eğilimlerini ölçme amacıyla oldukça sık bir şekilde kullanılmaktadır.

Likert ölçeği bir kişinin tek bir konuya karşı gösterdiği tutumla ilişkili olarak hazırlanmış cümle serisi içermektedir. Bu ölçeklerde iki tür cümle yapısı görülmektedir. Birinci tip, konuya karşı olumlu bir tutumu gösteren onaylama cümleleridir. İkinci tipse konuya karşı olumsuz bir tutumu gösteren onaylama cümleleridir. Likert ölçeğinde bu tür olumlu ve olumsuz cümleler yaklaşık eşit sayıda oluşturulmaya çalışılmaktadır. Bu ölçeğin en yaygın kullanımı, ölçeğin uygulandığı cevaplayıcıların her bir cümleyi onaylama derecesini belirtmesi amacıyla yönlendirilmesidir. Ölçekte bireye açık bir cümle sunulmakta ve bu cümlenin onun görüşlerini ne ölçüde yansıttığı sorulmaktadır. Likert ölçeğinde ikili, üçlü, dörtlü, beşli, altılı ve yedili seçenekler kullanılmakta ancak en yaygın şekilde beşli ölçek tercih edilmektedir. Tutumlara ilişkin değişkenlerin derecelendirilerek ifade edilmesi, bu derecelerin birbirleriyle karşılaştırılmalarını sağlamaktadır (Köklü, 1995, 88-89). Her bilimsel araştırmada olduğu gibi, tutum araştırmacısının kendisine sorup cevap arayacağı "neyi, niçin, nasıl araştıracağım?” sorularıdır. "Neyi?” sorusuna cevap tutumun konusunu, "niçin?” sorusu tutumun amacını ve varsayımlarını, "nasıl?” sorusu da tutum araştırma tekniklerini kapsamaktadır (Arslantürk, 2001, 174).

\section{Araştırmanın Yöntemi}

Çalışmanın alan araştırması kısmı nicel bir araştırma desenine sahip olmakla birlikte, bu nicel deseni güçlendirmek amacıyla derinlemesine görüşmeler yoluyla elde edilen nitel veriler de kullanılmıştır. İlk olarak nitel veri toplama tekniği olarak yarı-yapılandırılmış görüşme formu düzenlenmiştir. 2012-2013 Eğitim-Öğretim Yılı Bahar Dönemi’nde Akdeniz Üniversitesi Edebiyat Fakültesi bünyesinde görev yapmakta olan 41 erkek öğretim üyesinin 29'unun baba olduğu tespit edilmiş, bu 29 öğretim üyesi baba içinden kasıtlı örneklem yoluyla belirlenmiş -yeni baba olmuş, en az iki çocuğu olan, engelli çocuğu olan ve hem baba hem de engelli olan- 5 öğretim üyesiyle mülakatlar gerçekleştirilmiştir. Ses kayıt cihazı aracılığıyla kaydedilen görüşmeler, deşifre edildikten sonra nicel verilere ulaşmamızı sağlayacak anket formunda yer alan ifadeler oluşturulmuştur.

Sayılar aracılığıyla ifade edebileceğimiz ve bu açıdan daha nesnel olan verilere ulaşmak için Likert tipi ölçek yardımıyla baba adayı olan erkek üniversite öğrencilerine anket formu uygulanmıştır. Ölçekte yer alan ifadelerin katılma dereceleri kesinlikle katılıyorum (5), katılıyorum (4), karasızım (3), katılmıyorum (2) ve kesinlikle katılmıyorum (1) şeklinde düzenlenmiştir. Likert ölçeğinin yanı sıra öğrencilere annelerinin eğitim düzeyi, babalarının eğitim düzeyi, ailelerinin nerede yaşadığı, ailelerinin aylık ortalama geliri ve ailelerinin kaçıncı çocuğu olduklarına ilişkin beş sorudan oluşan babalık tutumunun oluşması açısından öncelikli etkiye sahip sosyo-demografik değişkenlerin sorgulandığı sorular da yöneltilmiştir. Düzenlenen anket formları, araştırmanın alt evreni içinden seçilen 280 erkek öğrenciye uygulanmıştır.

Araştırma kapsamında gerçekleştirilen evren, çalışma evreni ve alt evren tanımlamalarıysa şu şekilde düzenlenmiştir: 
Evren: Baba adayı olan tüm erkek üniversite öğrencileridir. Bu evren oldukça soyuttur ve tümüne ulaşılması neredeyse mümkün değildir.

Çalışma Evreni: Akdeniz Üniversitesi’nde öğrenim gören erkek öğrenciler olarak belirlenmiştir.

Alt Evren: Akdeniz Üniversitesi Edebiyat Fakültesi’nde (2012-2013 Eğitim-Öğretim Yılı Bahar Dönemi'nde Akdeniz Üniversitesi, Edebiyat Fakültesi bünyesinde 1024'ü erkek, 1269'u kız olmak üzere toplam 2293 öğrenci aktif [ders kaydını yapmış, okuyan] bir şekilde öğrenim görmektedir) öğrenim gören erkek öğrenciler olarak belirlenmiştir. Tüm bunlara bağlı olarak alt evren tanımlanırken elde edilen sonuçların genelleme yapılabilir bir gruptan alınabilmesi hedeflenmiştir. Söz konusu alt evren içinden, hakkında görüş bildirebilecek ve alt evreni temsil edebilecek erkek öğrencilerden oluşan bir örneklem grubu kasıtlı örneklem yoluyla seçilmiștir. 2012-2013 Eğitim-Öğretim Yılı Bahar Dönemi’nde Akdeniz Üniversitesi, Edebiyat Fakültesi bünyesinde aktif (ders kaydını yapmış, halen öğrenim gören) bir şekilde öğrenim görmekte olan 1024 erkek öğrenci bulunmaktadır. Bu alt evren içinden (+/-) \% 5'lik kabul edilebilir hata payı ve \% 95 güvenirlik seviyesi ile önerilen örneklem büyüklüğü olan 280 erkek öğrenci araştırma kapsamına dâhil edilmiştir. Örneklemi oluşturan 280 erkek öğrenci Edebiyat Fakültesi bünyesinde yer alan ve öğrencisi olan bölümlerden seçilmiştir.

Alan araştırmasında elde edilen bulgular aracılığıyla sınanacak temel varsayımlar ise şu şekilde düzenlenmiştir:

- Erkeğin annesinin eğitim düzeyi babalığa ilişkin tutumlarını etkiler.

- Erkeğin babasının eğitim düzeyi babalığa ilişkin tutumlarını etkiler.

- Erkeğin ailesinin yaşadığı yer babalığa ilişkin tutumlarını etkiler.

- Erkeğin ailesinin sosyo-ekonomik düzeyi babalığa ilişkin tutumlarını etkiler.

- Erkeğin ailesinin kaçıncı çocuğu olduğu babalığa ilişkin tutumlarını etkiler.

Yukarıda belirtilen temel varsayımların yanı sıra, anket çalışmasında yer alan her bir ifade için Ho ve $\mathrm{H} 1$ şeklinde oluşturulan alt varsayımlar da bulunmaktadır. Örneğin, Annenizin eğitim düzeyi nedir? sorusuyla "Toplumda en önemli sosyalleşme aracı ailedir" ifadesi için oluşturulan Ho ve H1 alt varsayımları şu şekilde oluşturulmuştur:

Ho: Annenin eğitim düzeyi ile "Toplumda en önemli sosyalleşme aracı ailedir” ifadesi arasında anlamlı bir ilişki yoktur.

H1: Annenin eğitim düzeyi ile “Toplumda en önemli sosyalleşme aracı ailedir” ifadesi arasında anlamlı bir ilişki vardır.

Görüldüğü gibi her bir soru ve her bir ifade arasında anlamlı bir ilişki olup olmadığına yönelik oluşturulan Ho hipotezi olumsuz, H1 hipoteziyse olumlu bir yargı taşıyacak şekilde düzenlenmiştir.

Araştırmanın nitel verilerini elde etmek amacıyla gerçekleştirilen derinlemesine görüşmeler deşifre edilerek yazıya dökülmüş; nicel verilerse anket formunda yer alan kodlar kullanılarak Microsoft Excel programında bilgisayar ortamına aktarılmıştır. Nicel verilerin analizi IBM SPSS Statistics paket programı kullanılarak gerçekleştirilmiştir. Araştırma verilerinin girişi yapıldıktan sonra veri kontrolleri gerçekleştirilmiş ve sıklık analizi yapılarak ankete katılanların sorulara verdikleri yanıtların dağılımlarına ulaşılmıştır. İkinci olarak elde edilen yanıtlar güvenilirlik analizine tabi tutularak soruların istenen değerlendirmeyi hangi düzeyde gerçekleştirdikleri belirlenerek, güvenilirlik düzeyi ortaya koyulmuştur (Likert tipi ölçeğin ölçümünde Cronbach Alfa yöntemi kullanılır. Cronbach's alpha değeri 0 ile 1 arasında değişmekte olup, değer 0,5'ten büyük olduğunda güvenilir anlamı taşır. Bu değer 1'e yaklaştıkça güvenilirlik artar. Cronbach's alpha değeri: $£$ a $<0.40$ güvenilir değil, $0.40 £$ a $<0.60$ düşük güvenilirlikte, $0.60 £$ a $<0.80$ 
oldukça güvenilir, $0.80 £$ a $<1.00$ yüksek derecede güvenilir olarak yorumlanır). Çalışmanın Cronbach's alpha değerleri incelendiğinde alınan yanıtların yüksek düzeyde güvenilir oldukları görülmüş̧ür.

Tablo 1. Güvenilirlik Analizi

\begin{tabular}{|c|c|c|c|c|}
\hline \multicolumn{2}{|l|}{$\begin{array}{l}\text { Cronbach's } \\
\text {,906 }\end{array}$} & Alpha & N of Items & 58 \\
\hline \multicolumn{5}{|l|}{ Item-Total Statistics } \\
\hline & $\begin{array}{l}\text { Scale } \\
\text { Mean } \\
\text { if Item } \\
\text { Deleted }\end{array}$ & $\begin{array}{c}\text { Scale } \\
\text { Variance } \\
\text { if Item } \\
\text { Deleted }\end{array}$ & $\begin{array}{c}\text { Corrected } \\
\text { Item-Total } \\
\text { Correlation }\end{array}$ & $\begin{array}{c}\text { Cronbach's } \\
\text { Alpha } \\
\text { if Item } \\
\text { Deleted }\end{array}$ \\
\hline Toplumda en önemli sosyalleşme aracı ailedir. & 143,13 & 685,207 & ,247 & ,906 \\
\hline Aile içinde herkesin görevi farklıdır. & 143,33 & 686,177 & 310 & ,905 \\
\hline Toplumun devamını aile sağlar. & 143,48 & 690,887 & ,208 & ,906 \\
\hline Aile kurmak riskli bir iştir. & 142,38 & 690,229 & ,111 & ,908 \\
\hline Aile hayatı düzene sokar. & 143,20 & 683,614 & ,342 & ,905 \\
\hline Annelik duygusu ile babalık duygusu birbirinden farklıdır. & 143,33 & 688,071 & ,252 & ,906 \\
\hline $\begin{array}{l}\text { Kültürün gelecek nesillere aktarılması en etkin olarak ailede } \\
\text { olur. }\end{array}$ & 143,29 & 682,537 & ,340 & ,905 \\
\hline Anne aile içinde gizli reistir. & 143,12 & 689,446 & ,185 & ,906 \\
\hline $\begin{array}{l}\text { Erkeğe üstünlük statüsü verilmesi ataerkil yapıdan } \\
\text { kaynaklanmaktadır. }\end{array}$ & 143,31 & 695,974 & ,073 & ,907 \\
\hline Aynı cinsiyetten evlikler geçici niteliğe sahiptir. & 142,92 & 675,936 & ,357 & ,905 \\
\hline Anne çocuklarına babadan daha yakındır. & 143,10 & 686,846 & ,235 & ,906 \\
\hline Baba çocuğuna karşı baskıcı olmalıdır. & 141,32 & 670,703 & ,430 & ,904 \\
\hline Aile Türk toplumunun temel yapı taşıdır. & 143,42 & 682,145 & ,346 & ,905 \\
\hline $\begin{array}{l}\text { Kız çocuk ya da erkek çocuk sahibi olmak bir baba için } \\
\text { farklı anlamlar taşır. }\end{array}$ & 142,71 & 674,711 & ,359 & ,905 \\
\hline Aile kurmak dini olarak bir emirdir. & 142,18 & 675,277 & ,319 & ,905 \\
\hline Ailenin geçiminden sadece baba sorumlu değildir. & 143,29 & 699,956 &,- 007 & ,908 \\
\hline Evin reisi baba olan erkektir. & 142,39 & 666,813 & ,499 & ,903 \\
\hline $\begin{array}{l}\text { Çocuğun kulağını çekmek, tokat atmak dövmek anlamına } \\
\text { gelmez. }\end{array}$ & 141,86 & 661,280 & ,500 & ,903 \\
\hline Erkeğin en önemli görevi babalıktır. & 142,67 & 667,828 & 445 & ,904 \\
\hline $\begin{array}{l}\text { Erkekler babalarının hatalı olduğu davranışları örnek } \\
\text { almazlar. }\end{array}$ & 142,17 & 681,570 & ,264 & ,906 \\
\hline Baba kelimesi sadece cinsel anlam taşımaz. & 143,42 & 688,199 & ,294 & ,905 \\
\hline Babalık zor bir iştir. & 143,36 & 682,492 & ,372 & ,905 \\
\hline Erkek erkeğe veya kadın kadına evlilik hoş görülebilir. & 141,45 & 702,930 &,- 059 & ,910 \\
\hline Baba temizlik işleriyle ilgilenmez. & 141,73 & 662,906 &, 555 & ,902 \\
\hline Aile içinde öğrendiklerimiz hayatımızı kolaylaştırır. & 143,35 & 692,569 & ,181 & ,906 \\
\hline Evlatlık alınan bir çocuk, erkeğe babalık duygusu yaşatmaz. & 141,67 & 668,662 & ,487 & ,903 \\
\hline Çocuğun üzerinde babasının sözleri daha etkilidir. & 142,57 & 671,054 & 495 & ,903 \\
\hline Erkek baba olduktan sonra sadece ailesi için yaşar. & 142,37 & 664,556 & ,594 & ,902 \\
\hline $\begin{array}{l}\text { Çocuğumun özel günleri (doğum günü, sünnet vb.) için } \\
\text { kendi babamın bana yaptıklarını yaparım. }\end{array}$ & 141,92 & 672,585 & ,435 & ,904 \\
\hline Baba yeri geldiğinde çocuğunu dövmelidir. & 141,50 & 662,009 & ,520 & ,903 \\
\hline $\begin{array}{l}\text { Erkeğin babalık rolünü yerine getirebilmesindeki en etkili } \\
\text { faktör ekonomidir. }\end{array}$ & 142,42 & 679,535 & ,297 & ,905 \\
\hline
\end{tabular}




\begin{tabular}{|c|c|c|c|c|}
\hline Bir baba için hayatta sadece çocuğu olmalıdır. & 141,90 & 665,510 & ,555 & ,903 \\
\hline Babanın aile içindeki en önemli görevi güvenliği sağlamaktır. & 142,58 & 679,437 & ,346 & ,905 \\
\hline $\begin{array}{l}\text { Bir erkeğin erkekle evlenmesi veya bir kadının kadınla } \\
\text { evlenmesi sonucu aile kurulamaz. }\end{array}$ & 142,92 & 667,685 & ,414 & ,904 \\
\hline Erkek olmak ile baba olmak aynı anlamdadır. & 141,52 & 660,959 & ,586 & ,902 \\
\hline Engelli bir çocuğa sahip olmak toplumda hoş karşılanmaz. & 141,14 & 670,437 & ,425 & ,904 \\
\hline $\begin{array}{l}\text { Baba olmak her şeyden önce sorumluluk duygusuna sahip } \\
\text { olmayı gerektirir. }\end{array}$ & 143,64 & 695,721 & ,107 & ,906 \\
\hline $\begin{array}{l}\text { Sperm bankaları kişilerde babalık imgesinin gelişimi } \\
\text { açısından olumsuz etkiye sahiptir. }\end{array}$ & 142,76 & 669,287 & ,456 & ,904 \\
\hline Babalık bir erkeğin tadabileceği en güzel duygudur. & 143,29 & 671,075 & ,545 & ,903 \\
\hline Arabayı baba kullanmalıdır. & 141,88 & 668,650 & ,457 & ,904 \\
\hline $\begin{array}{l}\text { Bir anne, çocuğu için babadan daha fazla emek } \\
\text { harcamaktadır. }\end{array}$ & 142,96 & 672,918 & ,469 & ,904 \\
\hline $\begin{array}{l}\text { Yeni nesil babalar çocuğu döverek eğitmek anlayışına } \\
\text { sahiptirler. }\end{array}$ & 141,23 & 680,233 & ,306 & ,905 \\
\hline Erkekler babalığı ailelerinden öğrenirler. & 142,99 & 685,439 & ,255 & ,906 \\
\hline Pazara gitmek annenin görevidir. & 141,67 & 666,233 & ,515 & ,903 \\
\hline Baba olunca hayat daha anlamlı olur. & 143,02 & 673,130 & ,465 & ,904 \\
\hline Bir erkek 25 yaşından önce çocuk sahibi olmamalıdır. & 142,73 & 683,408 & ,225 & ,906 \\
\hline $\begin{array}{l}\text { Bir erkek babasını temel karakteristik özelliklerini (adil } \\
\text { olma, doğruluk gibi...) örnek almalıdır. }\end{array}$ & 143,20 & 686,897 & ,266 & ,905 \\
\hline Çocuğu olmayan erkeğe toplumda iyi gözle bakılmaz. & 141,57 & 671,924 & ,438 & ,904 \\
\hline $\begin{array}{l}\text { Bir erkeğin babalık duygusunu anlayabilmesi için çocuğuyla } \\
\text { çokça vakit geçirmesi gerekir. }\end{array}$ & 143,04 & 688,371 & 219 & ,906 \\
\hline $\begin{array}{l}\text { Baba çocuklarına harçlık vermek suretiyle görevini yerine } \\
\text { getirmiş olur. }\end{array}$ & 140,99 & 670,960 & ,429 & ,904 \\
\hline Erkek çocuklar babalarını örnek alır. & 143,07 & 676,147 & ,458 & ,904 \\
\hline $\begin{array}{l}\text { Engelli çocuk, babalık görevlerini yerine getirmekte } \\
\text { engeldir. }\end{array}$ & 141,39 & 669,808 & ,460 & ,904 \\
\hline $\begin{array}{l}\text { Babanın yasa ve toplumun belirlediği görevleri yerine } \\
\text { getirmesiyle annenin yükü azalmaktadır. }\end{array}$ & 142,94 & 681,377 & ,354 & ,905 \\
\hline Herkes baba olamaz. & 143,14 & 680,909 & ,285 & ,905 \\
\hline $\begin{array}{l}\text { Çocuğunu döven babalar mutlaka kendi babalarından dayak } \\
\text { yemişlerdir. }\end{array}$ & 142,71 & 678,684 & ,380 & ,904 \\
\hline Bir baba çocuğunun hem annesi hem babası olamaz. & 142,43 & 668,946 & ,408 & ,904 \\
\hline Baba olmak için öncelikle erkek olmak gerekir. & 143,00 & 669,637 & ,464 & ,904 \\
\hline $\begin{array}{l}\text { Engelli çocuğa sahip bir baba, bazı sorumluluklarını yerine } \\
\text { getirmese de olur. }\end{array}$ & 141,25 & 667,522 & ,458 & ,904 \\
\hline
\end{tabular}

Çalışma kapsamında katılımcıların ifadelere katılma dereceleriyle sosyo-demografik özelliklere ilişskin soruların yanıtları arasında anlamlı bir ilişki olup olmadığını belirlemek amacıyla Ki-kare ( $\chi 2)$ bağımsızlık testleri uygulanmış ve anlamlı farklılaşmanın olduğu bulgular çapraz tablolarla açıklanmıştır. 5'li Likert tipi sorularla gerçekleştirilen Ki-kare $(\chi 2)$ bağımsızlık testlerinin sonuçları incelendiğinde, hücrelerde \% 25'ten fazla miktarda 5'ten küçük değer gözlenen çok sayıda sonuç olduğu yani örneklemin yetersiz olduğu tespit edildiği için örneklemin gücünü arttırmak gerektiğine karar verilmiştir. Bu doğrultuda 5'li Likert tipi olan ölçek 3'lü Likert tipi olarak yeniden kodlanmıştır. Katılımcıların Likert ölçeğinde yer alan her bir ifade için verdikleri cevapların dağılımlarını daha net değerlendirebilmek amacıyla yeniden kategorilendirdiğimizde katılma dereceleri şu şekilde düzenlenmiştir: 
- Katılıyorum (Kesinlikle katılıyorum ve katılıyorum cevaplarının toplamı)

- Kararsızım

- Katılmıyorum (Katılmıyorum ve kesinlikle katılmıyorum cevaplarının toplamı)

Buna ek olarak, (S1) Annenizin eğitim düzeyi, (S2) Babanızın eğitim düzeyi ve (S4) Ailenizin aylık ortalama geliri sorularının cevap seçenekleri de düzenlenmiştir. Annenin ve babanın eğitim düzeyi sorularının cevap seçenekleri okur-yazar değil, ilköğretim, lise ve yükseköğretim şeklinde; ailenin aylık ortalama geliri sorusunun cevapları 0-750 TL, 751-1500 TL, 1501-3000 TL ve 3000 TL ve üzeri şeklinde yeniden düzenlenmiştir. Yapılan düzenlemeler sonucunda yeniden kodlanan veriler bir kez daha Ki-kare $(\chi 2)$ bağımsızlık testlerine tabi tutulmuştur.

\section{Alan Araştırmasından Elde Edilen Verilerin Analizi}

Çalışma kapsamında gerçekleştirilen alan araştırmasında ilk olarak katılımcılara yöneltilen annelerinin eğitim düzeyi, babalarının eğitim düzeyi, ailelerinin nerede yaşadığı, ailerinin aylık ortalama geliri ve ailelerinin kaçıncı çocuğu olduklarına ilişkin sorulara verdikleri cevaplar değerlendirilmektedir. Şimdi, katılımcıların sosyo-demografik özelliklerine göre dağılımlarına ilişkin elde edilen veriler sunulmaktadır.

- Katılımcıların annelerinin eğitim durumlarına ilişkin veriler:

Katılımcıların annelerinin eğitim durumlarına göre dağılımları incelendiğinde, \% 22,5'inin okur-yazar değil, \% 11,1'inin okur-yazar, \% 23,9'unun ilkokul, \% 9,6'sının ortaokul, \% 20,4'ünün lise, \% 10,4'ünün yüksekokul/üniversitesi ve \% 0,4'ünün master/doktora düzeyinde eğitime sahip bireylerden oluştuğu görülmektedir.

- Katılımcıların babalarının eğitim durumlarına ilişkin veriler

Katılımcıların babalarının eğitim durumlarına göre dağılımları incelendiğginde, \% 6,1'inin okur-yazar değil, \% 10,0'ının okur-yazar, \% 27,1'inin ilkokul, \% 11,8'inin ortaokul, \% 24,3'ünün lise, \% 17,9'unun yüksekokul/üniversite ve \% 2,5'inin master/doktora düzeyinde eğitime sahip bireylerden oluştuğu görülmektedir.

- Katılımcıların ailelerinin nerede yaşadığına ilişkin veriler

Katılımcıların ailerinin nerede (Antalya/diğer) yaşadıklarına göre dağılımları incelendiğinde, \% 19,3'ünün Antalya'da, \% 80,4'ünün Antalya dışında yaşayan bireyler olduğu görülmektedir.

- Katılımcıların ailelerinin aylık ortalama gelirine ilişkin veriler:

Katılımcıların ailelerinin aylık ortalama gelirlerine göre dağılımları incelendiğinde, \% 18,9'unun 0-750 TL arası, \% 28,9'unun 751-1500 TL arası, \% 23,6'sının 1501-2250 TL arası, \% 11,4'ünün 2251-3000 TL arası, \% 3,6'sının 3001-3750 TL arası, \% 3,6'sının 3751-4500 TL arası, \% 3,6'sının 4501-5250 TL arası, \% 5’inin 5251 TL ve üstü gelire sahip bireylerden oluştuğu görülmektedir.

- Katılımcıların ailelerinin kaçıncı çocuğu olduğuna ilişkin veriler:

Katılımcılarının ailelerinin kaçıncı çocuğu olduğuna ilişkin dağılımları incelendiğinde, \% 9,3’ünün tek çocuk, \% 33,6'sının ilk çocuk, \% 24,6'sının ikinci çocuk, \% 12,5'inin üçüncü çocuk, \% 19,6’sının diğer (4. ve üzeri) oldukları görülmektedir.

İkinci olarak katılımcıların Likert ölçeğinde yer alan her bir ifadeye ilişkin verdikleri cevapların yüzdelik dağılımları incelenmektedir. Aşağıda yer alan tabloda katılımcıların her bir ifade için verdikleri cevapların (kesinlikle katılıyorum, katılıyorum, kararsızım, katılmıyorum, kesinlikle katılmıyorum) yüzelik dağılımları verilmektedir. 
Tablo 2. Katılımcıların Likert Ölçeğinde Yer Alan İfadelere Verdikleri Cevapların Dağılımı (\%)

\begin{tabular}{|c|c|c|c|c|c|}
\hline & 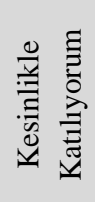 & 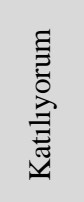 & 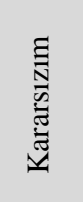 & 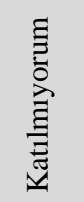 & 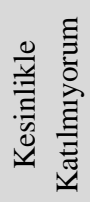 \\
\hline Toplumda en önemli sosyalleşme aracı ailedir. & $\underline{45,0}$ & 32,9 & 8,2 & 12,5 & 1,4 \\
\hline Aile içinde herkesin görevi farklıdır. & 43,6 & $\underline{47,9}$ & 4,3 & 2,5 & 1,8 \\
\hline Toplumun devamını aile sağlar. & $\underline{57,1}$ & 33,9 & 6,1 & 1,4 & 1,4 \\
\hline Aile kurmak riskli bir iştir. & $\underline{29,6}$ & 22,5 & 11,8 & 24,3 & 10,7 \\
\hline Aile hayatı düzene sokar. & $\underline{42,5}$ & 42,1 & 8,6 & 6,1 & ,7 \\
\hline Annelik duygusu ile babalık duygusu birbirinden farklıdır. & $\underline{49,3}$ & 37,9 & 8,6 & 2,9 & 1,4 \\
\hline Kültürün gelecek nesillere aktarılması en etkin olarak ailede olur. & $\underline{47,1}$ & 36,1 & 10,0 & 4,3 & 2,1 \\
\hline Anne aile içinde gizli reistir. & $\underline{42,9}$ & 36,4 & 9,6 & 8,9 & 1,8 \\
\hline Erkeğe üstünlük statüsü verilmesi ataerkil yapıdan kaynaklanmaktadır. & $\overline{49,6}$ & 31,8 & 10,7 & 6,4 & 1,4 \\
\hline Aynı cinsiyetten evlikler geçici niteliğe sahiptir. & $\underline{41,1}$ & 20,7 & 20,7 & 8,9 & 6,4 \\
\hline Anne çocuklarına babadan daha yakındır. & $\underline{40,4}$ & 35,4 & 13,9 & 7,5 & 2,9 \\
\hline Baba çocuğuna karşı baskıcı olmalıdır. & 7,9 & 14,6 & 8,9 & $\underline{36,4}$ & 31,1 \\
\hline Aile Türk toplumunun temel yapı taşıdır. & $\underline{59,6}$ & 25,4 & 6,8 & 5,4 & 2,1 \\
\hline Kız çocuk ya da erkek çocuk sahibi olmak bir baba için farklı anlamlar taşır. & 30,0 & $\underline{36,1}$ & 11,4 & 12,1 & 10,4 \\
\hline Aile kurmak dini olarak bir emirdir. & 21,4 & $\underline{22,9}$ & 18,9 & 17,9 & 18,6 \\
\hline Ailenin geçiminden sadece baba sorumlu değildir. & $\underline{45,4}$ & 42,1 & 3,2 & 6,4 & 2,9 \\
\hline Evin reisi baba olan erkektir. & 21,1 & $\underline{27,5}$ & 22,1 & 20,7 & 8,6 \\
\hline Çocuğun kulağını çekmek, tokat atmak dövmek anlamına gelmez. & 16,4 & 20,4 & 16,4 & 21,1 & $\underline{25,0}$ \\
\hline Erkeğin en önemli görevi babalıktır. & $\underline{34,3}$ & 24,3 & 17,9 & 13,6 & 8,9 \\
\hline Erkekler babalarının hatalı olduğu davranışları örnek almazlar. & 18,2 & 18,9 & $\underline{28,6}$ & 22,5 & 11,1 \\
\hline Baba kelimesi sadece cinsel anlam taşımaz. & $\underline{\mathbf{5 1 , 1}}$ & 37,1 & 8,2 & 2,5 & 1,1 \\
\hline Babalık zor bir iştir. & $\underline{53,2}$ & 31,1 & 9,3 & 4,3 & 1,8 \\
\hline Erkek erkeğe veya kadın kadına evlilik hoş görülebilir. & 12,5 & 12,9 & 17,1 & 18,6 & $\underline{38,2}$ \\
\hline Baba temizlik işleriyle ilgilenmez. & 11,1 & 18,9 & 16,8 & $\underline{33,6}$ & 18,6 \\
\hline Aile içinde öğrendiklerimiz hayatımızı kolaylaştırır. & 43,9 & $\underline{44,3}$ & 8,6 & 2,5 & ,7 \\
\hline Evlatlık alınan bir çocuk, erkeğe babalık duygusu yaşatmaz. & 9,6 & 12,9 & $\underline{29,6}$ & 27,5 & 20,4 \\
\hline Çocuğun üzerinde babasının sözleri daha etkilidir. & 19,6 & $\underline{36,8}$ & $\overline{23,9}$ & 13,6 & 5,0 \\
\hline Erkek baba olduktan sonra sadece ailesi için yaşar. & 16,1 & $\underline{29,6}$ & 27,1 & 20,7 & 6,1 \\
\hline $\begin{array}{l}\text { Çocuğumun özel günleri (doğum günü, sünnet vb.) için kendi babamın } \\
\text { bana yaptıklarını yaparım. }\end{array}$ & 11,8 & 19,3 & 24,6 & $\underline{32,9}$ & 11,4 \\
\hline Baba yeri geldiğinde çocuğunu dövmelidir. & 11,1 & 13,9 & 17,5 & $\underline{25,7}$ & 31,1 \\
\hline $\begin{array}{l}\text { Erkeğin babalık rolünü yerine getirebilmesindeki en etkili faktör } \\
\text { ekonomidir. }\end{array}$ & 20,0 & $\underline{34,3}$ & 17,1 & 20,7 & 7,9 \\
\hline Bir baba için hayatta sadece çocuğu olmalıdır. & 9,3 & 26,1 & 20,4 & $\underline{32,1}$ & 11,4 \\
\hline Babanın aile içindeki en önemli görevi güvenliği sağlamaktır. & 17,1 & $\underline{47,9}$ & 13,6 & 16,8 & 4,3 \\
\hline $\begin{array}{l}\text { Bir erkeğin erkekle evlenmesi veya bir kadının kadınla evlenmesi sonucu } \\
\text { aile kurulamaz. }\end{array}$ & $\underline{48,6}$ & 20,7 & 9,6 & 8,2 & 12,5 \\
\hline Erkek olmak ile baba olmak aynı anlamdadır. & 10,0 & 15,0 & 14,6 & $\underline{37,9}$ & 22,5 \\
\hline Engelli bir çocuğa sahip olmak toplumda hoş karşılanmaz. & 8,6 & 10,7 & 11,1 & 28,2 & $\underline{40,0}$ \\
\hline $\begin{array}{l}\text { Baba olmak her şeyden önce sorumluluk duygusuna sahip olmayı } \\
\text { gerektirir. }\end{array}$ & $\underline{67,1}$ & 25,4 & 3,2 & 2,9 & 1,4 \\
\hline $\begin{array}{l}\text { Sperm bankaları kişilerde babalık imgesinin gelişimi açısından olumsuz } \\
\text { etkiye sahiptir. }\end{array}$ & $\underline{36,1}$ & 21,4 & 26,8 & 8,6 & 7,1 \\
\hline Babalık bir erkeğin tadabileceği en güzel duygudur. & $\underline{55,0}$ & 25,4 & 12,9 & 4,6 & 1,8 \\
\hline Arabayı baba kullanmalıdır. & $\overline{15,4}$ & 18,9 & 18,6 & $\underline{33,6}$ & 13,2 \\
\hline
\end{tabular}




\begin{tabular}{|c|c|c|c|c|c|}
\hline Bir anne, çocuğu için babadan daha fazla emek harcamaktadır. & 32,9 & $\underline{37,1}$ & 13,6 & 11,8 & 4,3 \\
\hline Yeni nesil babalar çocuğu döverek eğitmek anlayışına sahiptirler. & 6,4 & 9,3 & 12,9 & $\underline{39,6}$ & 31,1 \\
\hline Erkekler babalığı ailelerinden öğrenirler. & 30,4 & $\underline{44,6}$ & 12,9 & 7,1 & 3,9 \\
\hline Pazara gitmek annenin görevidir. & 9,6 & 14,6 & 18,2 & $\underline{40,4}$ & 16,4 \\
\hline Baba olunca hayat daha anlamlı olur. & $\underline{38,9}$ & 35,4 & 15,4 & 6,8 & 3,2 \\
\hline Bir erkek 25 yaşından önce çocuk sahibi olmamalıdır. & $\underline{33,6}$ & 30,0 & 15,7 & 11,1 & 9,3 \\
\hline $\begin{array}{l}\text { Bir erkek babasını temel karakteristik özelliklerini (adil olma, doğruluk } \\
\text { gibi...) örnek almalıdır. }\end{array}$ & 37,1 & $\underline{45,7}$ & 8,9 & 6,1 & 1,8 \\
\hline Çocuğu olmayan erkeğe toplumda iyi gözle bakılmaz. & 7,1 & 16,8 & 18,2 & $\underline{35,0}$ & 20,7 \\
\hline $\begin{array}{l}\text { Bir erkeğin babalık duygusunu anlayabilmesi için çocuğuyla çokça vakit } \\
\text { geçirmesi gerekir. }\end{array}$ & 29,6 & $\underline{49,6}$ & 9,6 & 7,5 & 3,2 \\
\hline Baba çocuklarına harçlık vermek suretiyle görevini yerine getirmiş olur. & 8,2 & 7,1 & 6,1 & 31,1 & $\underline{47,1}$ \\
\hline Erkek çocuklar babalarını örnek alır. & 36,1 & $\underline{40,0}$ & 13,6 & 6,8 & 25,8 \\
\hline Engelli çocuk, babalık görevlerini yerine getirmekte engeldir. & 7,5 & 12,1 & 20,4 & $\underline{29,3}$ & $\underline{29,3}$ \\
\hline $\begin{array}{l}\text { Babanın yasa ve toplumun belirlediği görevleri yerine getirmesiyle annenin } \\
\text { yükü azalmaktadır. }\end{array}$ & 26,4 & $\underline{48,2}$ & 12,9 & 9,6 & 2,5 \\
\hline Herkes baba olamaz. & $\underline{48,6}$ & 26,4 & 8,9 & 6,1 & 7,1 \\
\hline Çocuğunu döven babalar mutlaka kendi babalarından dayak yemişlerdir. & 21,1 & $\underline{37,1}$ & 25,0 & 11,1 & 4,6 \\
\hline Bir baba çocuğunun hem annesi hem babası olamaz. & $\underline{29,3}$ & 24,6 & 13,9 & 18,2 & 13,6 \\
\hline Baba olmak için öncelikle erkek olmak gerekir. & $\underline{47,5}$ & 24,3 & 12,9 & 10,4 & 6,1 \\
\hline Engelli çocuğa sahip bir baba, bazı sorumluluklarını yerine getirmese de olur. & 10,0 & 10,7 & 15,0 & 23,2 & $\underline{40,7}$ \\
\hline
\end{tabular}

Likert ölçeğinde karışık bir şekilde yer alan 58 ifadeyi ilişkili olduğu konulara göre sınıflandırdığımızda şu şekilde gruplar oluşturulmuştur:

- Aile, evlilik ve çocuk ile ilgili ifadeler

- Anne(lik) ile ilgili ifadeler

- Erkek(lik) ve baba(lık) ile ilgili ifadeler

Tablo 3. Likert Ölçeğinde Yer Alan Aile, Evlilik ve Çocuk ile İlgili İfadeler

\begin{tabular}{|c|c|c|c|}
\hline Aile, Evlilik ve Çocuk ile İlgili İfadeler & 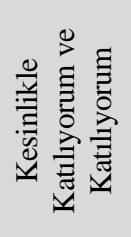 & 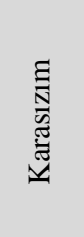 & 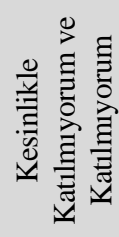 \\
\hline Toplumda en önemli sosyalleşme aracı ailedir. & $\underline{77,9}$ & 8,2 & 13,9 \\
\hline Kültürün gelecek nesillere aktarılması en etkin olarak ailede olur. & $\overline{83,2}$ & 10,0 & 6,4 \\
\hline Aile içinde herkesin görevi farklıdır. & $\overline{91,5}$ & 4,3 & 4,3 \\
\hline Toplumun devamını aile sağlar. & $\underline{91,0}$ & 6,1 & 2,8 \\
\hline Aile Türk toplumunun temel yapı taşıdır. & $\mathbf{8 5 , 0}$ & 6,8 & 7,5 \\
\hline Aile içinde öğrendiklerimiz hayatımızı kolaylaştırır. & $\overline{\mathbf{8 8 , 2}}$ & 8,6 & 3,2 \\
\hline Aile hayatı düzene sokar. & $\overline{\mathbf{8 4 , 6}}$ & 8,6 & 6,8 \\
\hline Aile kurmak dini olarak bir emirdir. & $\underline{44,3}$ & 18,9 & 36,5 \\
\hline Aile kurmak riskli bir iştir. & $\underline{52,1}$ & 11,8 & 34,7 \\
\hline $\begin{array}{l}\text { Bir erkeğin erkekle evlenmesi veya bir kadının kadınla evlenmesi sonucu } \\
\text { aile kurulamaz. }\end{array}$ & $\underline{69,3}$ & 9,6 & 20,7 \\
\hline Aynı cinsiyetten evlikler geçici niteliğe sahiptir. & $\underline{61,8}$ & 20,7 & 15,3 \\
\hline Erkek erkeğe veya kadın kadına evlilik hoş görülebilir. & 25,4 & 17,1 & $\underline{56,8}$ \\
\hline Çocuğun kulağını çekmek, tokat atmak dövmek anlamına gelmez. & 36,8 & 16,4 & $\underline{46,1}$ \\
\hline Engelli bir çocuğa sahip olmak toplumda hoş karşılanmaz. & 19,3 & 11,1 & $\underline{68,2}$ \\
\hline
\end{tabular}


Tablo 4. Likert Ölçeğinde Yer Alan Anne(lik) ile İlgili İfadeler

\begin{tabular}{|c|c|c|c|}
\hline Anne(lik) ile İlgili İfadeler & 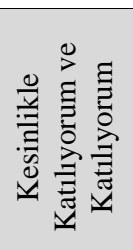 & 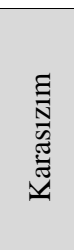 & 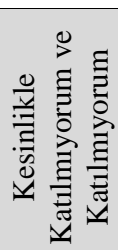 \\
\hline Anne aile içinde gizli reistir. & 79,3 & 9,6 & 10,7 \\
\hline Annelik duygusu ile babalık duygusu birbirinden farklıdır. & $\overline{\overline{87,2}}$ & 8,6 & 4,3 \\
\hline Anne çocuklarına babadan daha yakındır. & $\overline{\overline{75,8}}$ & 13,9 & 10,4 \\
\hline Bir anne, çocuğu için babadan daha fazla emek harcamaktadır. & $\overline{\mathbf{7 0 , 0}}$ & 13,6 & 16,1 \\
\hline Pazara gitmek annenin görevidir. & $\overline{24,2}$ & 18,2 & $\underline{56,8}$ \\
\hline
\end{tabular}

Tablo 5. Likert Ölçeğinde Yer Alan Erkek(lik) ve Baba(lık) ile İlgili İfadeler

\begin{tabular}{|c|c|c|c|}
\hline Erkek(lik) ve Baba(lık) ile İlgili İfadeler & 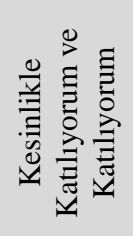 & 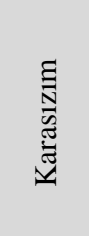 & 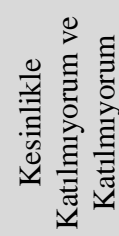 \\
\hline Erkeğe üstünlük statüsü verilmesi ataerkil yapıdan kaynaklanmaktadır. & $\underline{81,4}$ & 10,7 & 7,8 \\
\hline Evin reisi baba olan erkektir. & $\overline{\mathbf{4 8 , 6}}$ & 22,1 & 29,3 \\
\hline Erkeğin en önemli görevi babalıktır. & $\overline{\underline{58,6}}$ & 17,9 & 22,5 \\
\hline Erkek olmak ile baba olmak aynı anlamdadır. & $\overline{25,0}$ & 14,6 & $\underline{60,4}$ \\
\hline Baba olmak için öncelikle erkek olmak gerekir. & $\underline{71,8}$ & 12,9 & 16,5 \\
\hline Herkes baba olamaz. & $\underline{75,0}$ & 8,9 & 13,2 \\
\hline Baba kelimesi sadece cinsel anlam taşımaz. & $\underline{88,2}$ & 8,2 & 3,6 \\
\hline Erkekler babalığı ailelerinden öğrenirler. & $\underline{75,0}$ & 12,9 & 11,0 \\
\hline Erkek çocuklar babalarını örnek alır. & $\underline{76,1}$ & 13,6 & 32,6 \\
\hline Erkekler babalarının hatalı olduğu davranışları örnek almazlar. & 37,1 & 28,6 & $\underline{33,6}$ \\
\hline $\begin{array}{l}\text { Bir erkek babasını temel karakteristik özelliklerini (adil olma, doğruluk } \\
\text { gibi...) örnek almalıdır. }\end{array}$ & $\underline{82,8}$ & 8,9 & 7,9 \\
\hline Kız çocuk ya da erkek çocuk sahibi olmak bir baba için farklı anlamlar taşır. & $\underline{66,1}$ & 11,4 & 22,5 \\
\hline Babalık bir erkeğin tadabileceği en güzel duygudur. & $\underline{80,4}$ & 12,9 & 6,4 \\
\hline Baba olunca hayat daha anlamlı olur. & $\underline{74,3}$ & 15,4 & 10,0 \\
\hline Babalık zor bir iştir. & $\underline{84,3}$ & 9,3 & 6,1 \\
\hline Bir baba çocuğunun hem annesi hem babası olamaz. & $\underline{\mathbf{5 3 , 9}}$ & 13,9 & 31,8 \\
\hline Bir erkek 25 yaşından önce çocuk sahibi olmamalıdır. & $\underline{63,6}$ & 15,7 & 20,4 \\
\hline Baba olmak her şeyden önce sorumluluk duygusuna sahip olmayı gerektirir. & $\underline{\underline{92,5}}$ & 3,2 & 4,3 \\
\hline $\begin{array}{l}\text { Babanın yasa ve toplumun belirlediği görevleri yerine getirmesiyle annenin } \\
\text { yükü azalmaktadır. }\end{array}$ & $\underline{74,6}$ & 12,9 & 12,1 \\
\hline Bir baba için hayatta sadece çocuğu olmalıdır. & 35,4 & 20,4 & $\underline{43,5}$ \\
\hline Ailenin geçiminden sadece baba sorumlu değildir. & $\underline{87,5}$ & 3,2 & 9,3 \\
\hline Erkek baba olduktan sonra sadece ailesi için yaşar. & $\overline{\underline{45,7}}$ & 27,1 & 26,8 \\
\hline Erkeğin babalık rolünü yerine getirebilmesindeki en etkili faktör ekonomidir. & $\underline{54,3}$ & 17,1 & 28,6 \\
\hline Babanın aile içindeki en önemli görevi güvenliği sağlamaktır. & $\underline{65,0}$ & 13,6 & 21,1 \\
\hline Baba çocuklarına harçlık vermek suretiyle görevini yerine getirmiş olur. & $\overline{15,3}$ & 6,1 & $\underline{78,2}$ \\
\hline Baba temizlik işleriyle ilgilenmez. & 30,0 & 16,8 & $\underline{52,2}$ \\
\hline Arabayı baba kullanmalıdır. & 34,3 & 18,6 & $\underline{46,8}$ \\
\hline $\begin{array}{l}\text { Bir erkeğin babalık duygusunu anlayabilmesi için çocuğuyla çokça vakit } \\
\text { geçirmesi gerekir. }\end{array}$ & $\underline{79,2}$ & 9,6 & 10,7 \\
\hline
\end{tabular}




\begin{tabular}{|l|c|c|c|}
\hline $\begin{array}{l}\text { Çocuğumun özel günleri (doğum günü, sünnet vb.) için kendi babamın } \\
\text { bana yaptıklarını yaparım. }\end{array}$ & 31,1 & 24,6 & $\underline{\mathbf{4 4 , 3}}$ \\
\hline Çocuğun üzerinde babasının sözleri daha etkilidir. & $\underline{\mathbf{5 6 , 4}}$ & 23,9 & 18,6 \\
\hline Baba çocuğuna karşı baskıcı olmalıdır. & 22,5 & 8,9 & $\underline{\mathbf{6 7 , 5}}$ \\
\hline Baba yeri geldiğinde çocuğunu dövmelidir. & 25,0 & 17,5 & $\underline{\mathbf{5 6 , 8}}$ \\
\hline Çocuğunu döven babalar mutlaka kendi babalarından dayak yemişlerdir. & $\underline{\mathbf{6 8 , 2}}$ & 25,0 & 15,7 \\
\hline Yeni nesil babalar çocuğu döverek eğitmek anlayışına sahiptirler. & 15,7 & 12,9 & $\underline{\mathbf{7 0 , 7}}$ \\
\hline Çocuğu olmayan erkeğe toplumda iyi gözle bakılmaz. & 23,9 & 18,2 & $\underline{\mathbf{5 5 , 7}}$ \\
\hline $\begin{array}{l}\text { Sperm bankaları kişilerde babalık imgesinin gelişimi açısından olumsuz } \\
\text { etkiye sahiptir. }\end{array}$ & $\underline{\mathbf{5 7 , 5}}$ & 26,8 & 15,7 \\
\hline Evlatlık alınan bir çocuk, erkeğe babalık duygusu yaşatmaz. & 22,5 & 29,6 & $\underline{\mathbf{4 7 , 9}}$ \\
\hline Engelli çocuk, babalık görevlerini yerine getirmekte engeldir. & 19,6 & 20,4 & $\underline{\mathbf{5 8 , 6}}$ \\
\hline Engelli çocuğa sahip bir baba, bazı sorumluluklarını yerine getirmese de olur. & 20,7 & 15,0 & $\underline{\mathbf{6 3 , 9}}$ \\
\hline
\end{tabular}

Katılımcılara Yöneltilen Her Bir Soru ve İfadeye İlişkin Ki-kare ( $\chi 2)$ Bağımsızlık Testlerinin Uygulanması Sonucunda Elde Edilen Veriler

Çalışma kapsamında katılımcıların anket çalışmasındaki ifadelere katılma dereceleriyle her bir soru arasında anlamlı bir ilişki olup olmadığını saptamak amacıyla Ki-kare $(\chi 2)$ bağımsızlık testleri yapılmıştır. İstatistiksel testler sonucunda $\mathrm{p}<0,05$ şartını sağlayan ve Ki-kare $(\chi 2)$ bağımsızlık testlerinde hücrelerde gözlenen değerlerin, \% 25'den fazla oranda 5'ten küçük olmadığı bulgular tespit edilmiştir.

Likert ölçeğinde yer alan her bir ifadenin katılımcının annesinin eğitim düzeyi; babasının eğitim düzeyi; ailesinin nerede yaşadığı; ailesinin aylık ortalama geliri ve ailesinin kaçıncı çocuğu oluşu ile anlamlı bir ilişki olup olmadığını saptamak amacıyla gerçekleştirilen Ki-kare $(\chi 2)$ bağımsızlık testlerine ilişkin tablolar oluşturulmuştur. Anket çalışmasında yer alan soru ve ifadeler arasındaki ilişkiler incelendiğinde, sadece katılımcının annesinin eğitim düzeyi ile "Aile kurmak dini bir emirdir" ifadesi ve katılımcının ailesinin kaçıncı çocuğu olduğu ile "Erkekler babalarının hatalı olduğu davranışları örnek almazlar” ifadesi arasında anlamlı bir ilişkinin olduğu tespit edilmiştir.

Anket çalışmasında yer alan soru ve ifadeler arasında anlamlı bir ilişki olup olmadığına baktığımızda, sadece iki ifade arasında anlamlı bir ilişkinin olduğu gözlenmiştir. Bu nedenle anket çalışmasında yer alan kategorilerin yeniden düzenlenerek güçlendirilmesi ve Ki-kare $(\chi 2)$ bağımsızlık testlerinin tekrar yapılması gerekli görülmüştür. İlk olarak katılımcıların Likert ölçeğinde yer alan her bir ifade için verdikleri cevapların dağılımlarını daha net değerlendirebilmek amacıyla katılma dereceleri katılıyorum, karasızım ve katılmıyorum şeklinde; gelir düzeyi kategorileri 0-750 TL, 751-1500 TL, 1501-3000 TL ve 3000 TL-üzeri şeklinde; eğitim düzeyi kategorileriyse okur-yazar değil, ilköğretim, lise ve yükseköğretim şeklinde yeniden düzenlenmiştir. Böylece hem örneklemin gücü artırılmış hem de tabloların daha kolay ve anlaşılır bir şekilde yorumlanabilmesi sağlanmıştır. Bir kez daha uygulanan Ki-kare( $\chi 2)$ bağımsızlık testleri sonucunda aralarında anlamlı bir ilişki olduğu saptanan soru ve ifadelerse şunlardır:

(S1) Annenin eğitim düzeyiyle aralarında anlamlı bir ilişki olduğu tespit edilen ifadeler:

- Toplumda en önemli sosyalleşme aracı ailedir.

- Aynı cinsiyetten evlilikler geçici niteliğe sahiptir.

- Aile kurmak dini olarak bir emirdir.

- Evin reisi baba olan erkektir.

- Erkekler babalarının hatalı olduğu davranışları örnek almazlar.

- Çocuğun üzerinde babasının sözleri daha etkilidir.

- Bir baba için hayatta sadece çocuğu olmalıdır. 
- Bir baba çocuğunun hem annesi hem babası olamaz.

(S2) Babanın eğitim düzeyiyle aralarında anlamlı bir ilişki olduğu tespit edilen ifadeler:

- Toplumda en önemli sosyalleşme aracı ailedir.

- Erkeğe üstünlük statüsü verilmesi ataerkil yapıdan kaynaklanmaktadır.

- Anne çocuklarına babadan daha yakındır.

- Aile kurmak dini olarak bir emirdir.

- Evin reisi baba olan erkektir.

- Erkeğin en önemli görevi babalıktır.

- Baba temizlik işleriyle ilgilenmez.

- Çocuğun üzerinde babasının sözleri daha etkilidir.

- Erkek baba olduktan sonra sadece ailesi için yaşar.

- Bir baba için hayatta sadece çocuğu olmalıdır.

- Bir erkeğin erkekle evlenmesi veya bir kadının kadınla evlenmesi sonucu aile kurulamaz.

- Pazara gitmek annenin görevidir.

- Bir erkeğin babalık duygusunu anlayabilmesi için çocuğuyla çokça vakit geçirmesi gerekir.

- Çocuğunu döven babalar mutlaka kendi babalarından dayak yemişlerdir.

(S3) Ailenin yaşadığı yerle aralarında anlamlı bir ilişki olduğu tespit edilen ifadeler:

- Evin reisi baba olan erkektir.

- Bir baba için hayatta sadece çocuğu olmalıdır.

(S4) Ailenin aylık ortalama geliriyle aralarında anlamlı bir ilişki olduğu tespit edilen ifadeler:

Aile kurmak dini olarak bir emirdir.

Arabayı baba kullanmalıdır.

(S5) Ailenin kaçıncı çocuğu olduğuyla aralarında anlamlı bir ilişki olduğu tespit edilen ifadeler:

- Aynı cinsiyetten evlilikler geçici niteliğe sahiptir.

- Erkek erkeğe veya kadın kadına evlilik hoş görülebilir.

- Erkeğin babalık rolünü yerine getirebilmesindeki en etkili faktör ekonomidir.

- Bir baba için hayatta sadece çocuğu olmalıdır.

- Bir erkeğin erkekle evlenmesi veya bir kadının kadınla evlenmesi sonucu aile kurulamaz.

- Yeni nesil babalar çocuğu döverek eğitim anlayışına sahiptirler.

\section{Değerlendirme ve Sonuç}

Aileyi meydana getiren anne, baba ve çocuğa ait roller tarihsel süreç içinde sosyo-kültürel bağlamda değerlendirilebilmektedir. Anne ve baba gelecek nesillerin ve toplumun şekillenmesinde oldukça önemli bir etkiye sahiptir. Bu nedenle sosyal bilimlerin pek çok disiplininde farklı yönleriyle ele alınmaktadır. Başlangıçta biyolojik bir nitelik taşıyan annelik ve babalık olgusu daha sonraki süreçte hem bir kültür ürünü hem de kültürü oluşturan bir olgu olarak karşımıza çıkmaktadır. Farklı kültürel yapılarda gerçekleştirilen araştırmalar annelik ve babalığa özgü tutum ve davranışlardaki benzerlik ve farklılıkları ortaya koymaktadır.

Babalıkla ilgili çalışmalar 1980'li yıllardan önce başlamış ancak 1990'lı yıllarda yaygın bir biçimde tartışılır hale gelmiştir. Babalara yönelik bu ilginin artmasında ve babalık rolünün değişmesinde en önemli etkeninse, yine kadın olduğu ifade edilmektedir. Kadının toplum içindeki konumunun değişmesiyle birlikte erkeğin ve dolayısıyla babanın, tutum ve davranışlarında, görev ve sorumluluklarında önemli değişmeler yaşanmaktadır. Geleneksel aile yapısının çekirdek aileye dönüşmesi, çekirdek aile yapısı içindeki bireylerin rol ve sorumluluklarının değişmesi, kadının eğitim düzeyinin yükselmesi, çalışan kadın sayısının artması, kadının ekonomik yönden erkeklerden daha bağımsız hale gelmesi ve kadının tam gün dışarıda çalışmasına bağlı 
olarak erkeklerin ev işi ve çocuk bakımıyla ilgili sorumlulukları paylaşmaya başlaması gibi sosyo-kültürel yapıda yaşanan değişmelere bağlı olarak babalık olgusuna yeni anlamlar atfedilmektedir. Toplumun değer yargıları, geleneksel cinsiyet rolleri ve dolayısıyla annelik-babalık rollerine ilişkin tanımlamalar değiştikçe iyi bir anne ya da baba olmanın ve beraberinde getirdiği sorumlulukların da anlamları değişmekte ve çeşitlenmektedir.

18. yüzyıl ile 19. yüzyılın başlarına kadar olan dönemde Batı'da babaların en önemli görevi çocuklarına ahlaklı olmayı öğretmek ve onlarda gördükleri hataları düzeltmekti. Sanayi Devrimi sonrasında erkeklerin daha uzun saatler çalışmaya başlaması annelerin, babaların sorumluluklarını da üstlenmelerine yol açmıştır. Sanayi Devrimi'nin ortalarında babalar ahlak öğretmeni olmaktan çıkarak evin ekmeğini kazanan kişiler haline gelmiştir. 1940 ile 1965 yılları arasında yaşanan savaşlar babalık kavramına yeni bir tanım getirmiştir. Savaşa giden babaların birçoğunun dönmemesi sonucunda çalışan kadın sayısı artmış ve kadınlar erkeklerden bağımsız olarak yaşamayı öğrenmek zorunda kalmışlardır. Bu dönemde babaların varlığından çok yokluğunun çocukları nasıl etkileyebileceği sorgulanır olmuş ve babaların önemi yeniden vurgulanmaya başlanmıştır. Ahlak öğretmeni olma ve evin ekmeğini kazanma sorumluluklarının yanı sıra babaların erkek çocukların cinsel kimliğini kazanmalarında da önemli bir role sahip oldukları belirtilmiştir. 1970'li yıllarla birlikte babaların çocuklarının bakımına aktif bir şekilde katıldıkları gözlenmiştir. Bu dönemin yeni baba modeli geçmiştekilerden oldukça farklıdır. Yeni baba doğuma giren, bebeklik dönemlerinde de çocuklarıyla ilgilenen, yalnızca oyun oynamakla yetinmeyen, çocuk bakımına daha aktif bir şekilde katılan ve erkek çocuklarıyla olduğu kadar kız çocuklarıyla da ilgilenen bir baba modelidir. Eğitim ve gelir düzeyi gibi faktörlerin artışına bağlı olarak ev işleri, çocuk bakımı gibi konularda eşlerinin sorumluluğunu paylaşan babaların sayısını da artmaya başlamıştır.

Günümüzde farklı erkeklik ve babalık modellerinin varlığı kabul edilmekle birlikte, Sancar’ın (2009) gerçekleştirmiş olduğu araştırma, Türkiye'de egemen olan babalık modelinin evin geçimini sağlayan aile babası olduğunu ortaya koymuştur. Bununla birlikte günümüzde geleneksel değerler temelinde yer alan babalık ile modern babalık uygulamalarının bir arada olduğu da görülmüştür. Sancar, farklı babalık modellerinin farklı erkeklik modellerine tekabül ettiğini ve bunların her şeyden önce kır-kent ayrımı ve sınıfsal farkları oluşturan eğitim ve aile biçimlerine dayalı kültürel sermayeyle ilişkili olduğunu belirtmiştir. Türkiye'de en yaygın babalık biçimini, erkeğin geçim sorumluluğunu büyük ölçüde tek başına üstlendiği, kadınların sadece ev işi yaptıkları, kız çocukların okutulmakla birlikte erkek çocuklarla eşit görülmediği "modernleşmiş” aile babalığı şeklinde tanımlayan Sancar, araştırma sürecinde görüştüğü erkeklerin çoğunun babaları ile çatışmalı, mesafeli ve soğuk bir ilişkileri olduğunu da belirtmiştir.

Konuya ilişkin literatüre bakıldığında, Türkiye'de özellikle babalığa ilişkin tutum ve davranışları belirleyen etkenler konusunda gerçekleştirilen çalışmaların yetersiz olduğu ve konuyla ilgili araştırmalara gerek duyulduğu görülmüştür. Sosyo-kültürel ve ekonomik değişmelerin etkilerini sosyolojik olarak net bir şekilde toplumsal yapıdaki izdüşümleri üzerinde analizler, gözlemler, çıkarımlar ve değerlendirmeler yaparak ortaya koymak mümkündür. Nitekim bu çalışmada, toplumsal yapı inşasındaki değişmeler, toplumsal yapının oluşumunda etken faktörler olan aile ve babalık olguları üzerinden ortaya koyulmaya çalışılmıştır. Bu bağlamda yerli ve yabancı literatürün taranması, konuya ilişkin kaynaklara ulaşılması, mülakat ve anket uygulamalarını içeren alan araştırmasının uygulanması çalışmaya şeklini vermiş ve özellikle yüksek güvenirlilik katsayısına sahip olduğu ortaya konan bir Likert ölçeği kullanılarak geleceğin baba adayları olan erkek öğrencilere uygulanan anketlerle babalığa ilişkin tutum, davranış ve düşünceler elde edilmiştir. Erkek öğrencilere uygulanan anket formunun çalışmanın ana varsayımlarını içeren ilk 5 sorusu ankete katılan baba adaylarının anne ve babalarının eğitim düzeyleri, 
ailelerinin yaşadığı yer, ailelerinin gelir düzeyi ve baba adaylarının ailelerinin kaçıncı çocuğu oldukları bilgisi ve bunların babalık tutumuna etkileri doğrultusunda değerlendirmelere ulaşılmaya çalışılmıştır.

Daha önce de belirtildiği gibi toplumsallaşan, kültür edinen çocuğun yaşam boyu karşılaştığı kişiler içinde en önemlileri şüphesiz ki, anne ve babasıdır. Annelik ve babalık davranışlarını etkileyen faktörlerin bir kısmı topluma ya da kültürel bağlama özgü araştırmalar tarafından diğer bir kısmı da kültürler arası araştırmalar tarafından desteklenmektedir. Kadın ve erkeğin rollerinin birbirini tamamlaması üzerine kurulu olan geleneksel aile ve evlilik yapısı içindeki bireylerin sorumluluk alanları keskin sınırlarla belirlenmektedir. Bu sınırlar annelik ve babalık rolleri için de geçerli olmakta, çocukların sorumluluğunu anneler üstlenirken, baba otoriteyi ve gücü temsil etmektedir. Günümüz toplumlarının modern aile ve evlilik yapısı ise oldukça farklıdır. Erkeğin egemenliği üzerine kurulu geleneksel aile yapısı babanın her konuda tek söz sahibi olmasından uzaklaşarak, daha eşitlikçi bir ilişkiler ağına dönüşmektedir. Bu ailelerde çocuğa ilişkin konularda anne ve baba birlikte karar vermekte, çocuğa verilen önem ve değer artmaktadır. Yaşanan toplumsal değişmeler sonucunda aile yapısındaki değişmelere yönelik tartışmaların bir boyutu da, babalığa özgü tutum ve davranışlar üzerine odaklanmaktadır. Günümüzde erkeklerin (baba olanlar ve geleceğin muhtemel babaları) babalığa ilişkin tutum ve davranışlarında nelerin etkili olduğunun ve babalık olgusuna yükledikleri anlamların saptanması amacıyla yola çıkılan bu çalışmada, baba adaylarının babalığa ilişkin tutum ve davranışlarının oluşması ve gelişmesi sürecinde annelerinin ve babalarının eğitim düzeylerinin etkili olduğu saptamasını yapmak mümkün görünmektedir. 


\section{KAYNAKÇA}

Arslan, Ş. A. (2000). Ders Kitaplarında Cinsiyetçilik. Ankara: T.C. Başbakanlık Kadının Statüsü ve Sorunları Genel Müdürlüğü.

Arslantürk, Z. (2001). Sosyal Bilimler İ̧̧in Araştırma Metod ve Teknikleri. İstanbul: Çamlıca Yayınları.

Atmaca Koçak, A. (2004). “Türkiye'de Babaların Şimdiki Durumu, Baba Destek Programı Değerlendirme Raporu”. İstanbul: Boğaziçi Üniversitesi, 1-65.

Badinter, E. (1992). Annelik Sevgisi-17. Yüzyıldan Günümüze Bir Duygunun Tarihi. Çev.: Kamuran Çelik. İstanbul: AFA Yayınları.

Badinter, E. (2011). Kadınlık mı? Annelik mi?. Çev.: Ayşen Ekmekci. İstanbul: İletişim Yayınları.

Bağlı, M. T., \& Sevim, S. A. (2007). "Popüler Anababalık: Aile Dergileri Üzerine Bir Araştırma”. Yay. Haz.: Nihal Ahioğlu, \& Neslihan Güney. Popüler Kültür ve Çocuk, 127-158. Ankara: Dipnot Yayınları.

Baydar, N., \& Akçinar, B., \& İmer, N. (2012). “Çevre, Sosyoekonomik Bağlam ve Ana Babalık”. Der.: Melike Sayıl, \& Bilge Yağmurlu. Ana Babalı: Kuram ve Araştırma, 81-127. İstanbul: Koç Üniversitesi Yayınları.

Bora, A., \& Üstün, İ. (2008). Sıcak Aile Ortamı. İstanbul: TESEV Yayınları.

Cruzat, C., \& Aracena M. (2006). "Significado de la Paternidad en Adolescentes Varones del Sector SurOriente de Santiago”. PSYKHE, 15 (1), 29-44 (İsp.).

Çabuklu, Y. (2007). Toplumsal Kurgular ve Cinsiyetçilik. İstanbul: Everest Yayınları.

Çağdaş, A. (2003). Anne-Baba-Çocuk İletişimi. Konya: Eğitim Kitabevi Yayınları.

Diamond, J. (2006). Hırçın Erkek Sendromu. Çev.: İlker Gülfidan. İstanbul: Sistem Yayıncılık.

Eggebeen, D. J., \& Knoester, C. (2001). “Does Fatherhood Matter for Men?”. Journal of Marriage and Family, 63, 2, 381-393.

Eken, H. (2010). Rol Etkileşimi Bağlamında Kadın Subaylar. Konya: Palet Yayınları.

Güngörmüş, O. (1998). Ana-Baba Okulu. İstanbul: Remzi Kitabevi.

Güngörmüş-Özkardeş, O. (2010). Baba Olmak. İstanbul: Remzi Kitabevi.

Janzen, I. (2010). "Männer im Konflikt”. Traditionen, "Neue Vaterschaft” und Kinderlosigkeit. Tectum Verlag, Marburg (Alm.).

Kağıtçıbaşı, Ç. (2012). "Kültür ve Ana Babalık: Kuram ve Uygulama Çıkarsamaları”. Der.: Melike Sayıl, \& Bilge Yağmurlu. Ana Babalı: Kuram ve Araştırma, 61-79. İstanbul: Koç Üniversitesi Yayınları.

Kaila-Behm, A., \& Vehviläinen-Julkunen, K. (2000). "Ways of being a father: How first-time fathers and public health nurses perceive men as fathers”. International Journal of Nursing Studies, 37 (3), 199-205.

Kızılkaya, H. (2004). Anasoyluluktan Günümüze Kadın. İzmir: İlya Yayınevi.

Koçak Turhanoğlu, F. A. (2011). “Aile ve İlişkiler Ağı”. Eds. Aytül Kasapoğlu, \& Nadide Karkıner. Aile Sosyolojisi, 186-211. Eskişehir: T.C. Anadolu Üniversitesi Yayını.

Köklü, N. (1995). “Tutumların Ölçülmesi ve Likert Tipi Ölçeklerde Kullanılan Seçenekler”. Ankara Üniversitesi Eğitim Bilimleri Fakültesi Dergisi, Cilt: 28, Sayı: 2, 81-93.

Meuser, M. (2012). "Vaterschaft im Wandel, Herausforderungen, Optionen, Ambivalenzen”. Eds. Karin Böllert, \& Corinna Peter. Mutter + Vater = Eltern? Sozialer Wandel, Elternrollen und Soziale Arbeit, VS Verlag für Sozialwissenschaften, 63-80. Wiesbaden: Springer Fachmedien, (Alm.).

Navaro, L. (2007). Tapınağın Öbür Yüzü - Bağgllık ve Bağımlılık Üzerine. İstanbul: Remzi Kitabevi.

Olavarría, J. (1999). “Adolescentes/adolescentes: Qué poco sabemos de ellos”. Entre la II Cumbre y la detención de Pinochet. Chile: FLACSO, 255-278 (İsp.).

Onur, B. (2012). “Çocukluğun ve Çocuk Yetiştirmenin Tarihi”. Der.: Melike Sayıl, \& Bilge Yağmurlu. Ana Babalı: Kuram ve Araştırma, 19-59. İstanbul: Koç Üniversitesi Yayınları.

Onur, B. (2005). Türkiye'de Çocukluğun Tarihi. Ankara: İmge Kitabevi Yayınları.

Osherson, S. (1986). Finding our fathers: The unfinished business of manhood. New York: The Free Press.

Possinger, J. (2013). Vaterschaft im Spannungsfeld von Erwerbs- und Familienleben. "Neuen Vätern” auf der Spur. Wiesbaden: Springer VS (Alm.). 
Reed, E. (1994). Kadının Evrimi I-Anaerkil Klandan Ataerkil Aileye. Çev.: Şemsa Yeğin. İstanbul: Payel Yayınları.

Russell, B. (1999). Evlilik ve Ahlak. Çev.: Vasıf Eranus. İstanbul: Say Yayınları.

Sancar, S. (2009). Erkeklik: İmkânsız İktidar-Ailede, Piyasada ve Sokakta Erkekler. İstanbul: Metis Yayınları. Sayıl, M., \& Yağmurlu, B. (2012). “Türkiye’de Ana Babalık Çalışmalarına Bakış”. Der.: Melike Sayıl, \& Bilge Yağmurlu. Ana Babalık: Kuram ve Araştırma, 15-18. İstanbul: Koç Üniversitesi Yayınları.

Silah, M. (2005). Sosyal Psikoloji. Ankara: Seçkin Yayıncılık.

Snarey, J. (1993). How fathers care for the next generation: A four decade study. Cambridge: Harvard University Press.

Türkçe Sözlük (2009). Ankara: Türk Dil Kurumu Yayınları.

White, R. N.,“About fathers: Masculinity and the social construction of fatherhood”. Journal of Sociology, 30 (2), 119-131.

Yıldırım, E. (2009). “Toplumsal Değişme Sürecinde Aile”. Eds. Kadir Canatan, \& Ergun Yıldırım. Aile Sosyolojisi, 149-171. İstanbul: Açlım Kitap.

Yörükoğlu, A. (2007). Değissen Toplumda Aile ve Çocuk. İstanbul: Özgür Yayınları.

\section{İnternet Kaynakları}

Ailede Çocuk Eğitimi Araştırması (1995).

http://www.ailetoplum.gov.tr/upload/athgm.gov.tr/mce/eskisite/files/kutuphane_18_Aile_Cocuk_Egitimi _Arastirmasi.pdf / 13.01.2013 